\title{
Career Experience and Executive Performance: Evidence from Former Equity Research Analysts
}

\author{
Shawn X. Huang \\ Associate Professor of Accounting \\ Arizona State University \\ Artur Hugon \\ Associate Professor of Accounting \\ Arizona State University \\ Summer Z. Liu \\ Ph.D. Candidate \\ Arizona State University \\ Liwei Weng \\ Ph.D. Candidate \\ Arizona State University
}

Jan 2020

\begin{abstract}
:
This study examines CEOs and CFOs who have prior work experience as equity research analysts. Consistent with backgrounds in forecasting and valuation, we find these executives provide earnings guidance that is more accurate than that of other executives, and their M\&A transactions generate significantly higher announcement returns. For available CEOs and CFOs, we examine their track records as research analysts with respect to forecasting accuracy and stock recommendation profitability. We find a positive association between a record of past forecasting accuracy and more accurate earnings guidance, as well as a positive association between past stock recommendation profitability and M\&A announcement returns. Beyond these traits, we find these executives provide greater certainty in their answers to analysts during conference calls, especially when answering forward-looking questions. Finally, these executives' firms exhibit superior accounting and stock return performance. Overall, our evidence suggests that early career skill sets can shape top executive performance outcomes.
\end{abstract}

Keywords: CEO/CFO, Career experience, Equity analyst, M\&A, Earnings forecasts JEL Classifications: M41, G24, J24

\footnotetext{
We thank Bok Baik (HARC discussant), Andy Call, Lucile Faurel, Steve Kaplan, Dave Kenchington, Marcus Kirk (FEA discussant), Joseph Pacelli (FARS discussant), Maria Rykaczewski, and seminar participants at Arizona State University, 30th Annual Conference on Financial Economics and Accounting, 2020 Hawaii Accounting Research Conference, and 2020 Midyear Meeting of the Financial Accounting and Reporting Section for comments and suggestions. We thank Brian Bushee, Ian Gow and Daniel Taylor for their conference call data, Tim Loughran and Bill McDonald for their sentiment word lists, and Bill McDonald for additional insights into textual analysis and earnings call transcripts.
} 


\section{INTRODUCTION}

The neo-classical view of top executive performance espouses a limited role for idiosyncratic traits. That is, executive performance is largely determined by contracting and monitoring mechanisms, as well as the firm and industry economic landscape (Bertrand and Schoar 2003). In contrast, upperechelons theory posits that organizational outcomes are, at least in part, determined by executives' idiosyncratic characteristics (Hambrick and Mason 1984; Hambrick 2007). One strand of prior research utilizes a fixed-effect approach to show that Chief Executive Officers (CEOs) and Chief Financial Officers (CFOs) uniquely impact corporate practices and operations (e.g., Bertrand and Schoar 2003; Dyreng, Hanlon and Maydew 2010; Ge, Matsumoto and Zhang 2011). Peering into these effects, recent studies examine executive heterogeneity with respect to aspects such as education, personal characteristics, and career experience (Bamber, Jiang and Wang 2010; Custódio and Metzger 2013; Benmelech and Frydman 2015; Law and Mills 2017). The thrust of these studies is to tie general experience or traits to operational outcomes and corporate policies. For example, a background in the military service leads to more conservative investment (Benmelech and Frydman 2015) or tax planning (Law and Mills 2017).

In contrast, our interest is in specific experience. In particular, we investigate whether skill sets developed during formative years carryover and meaningfully impact top executive performance with respect to related tasks. We investigate this question by assembling a sample of CEO/CFOs who have prior work experience as equity research analysts. ${ }^{1}$ The equity research industry provides an excellent setting to address the importance of early career skill sets for several reasons. First, many career paths leading to top executive positions such as marketing, legal, and engineering are heterogeneous in nature. For example, a marketing executive might be involved in sales, advertising, media strategy, or

\footnotetext{
${ }^{1}$ We examine CEOs and CFOs as a combined group representing companies' top executives. For ease of exposition, we refer them as 'CEO/CFOs'.
} 
brand development; each one of these paths providing very different training and experiences. In comparison, forecasting earnings performance and valuing companies are standard features of the equity research analyst job. Second, forecasting and stock selection are not only standard, they are performed quite frequently and benefit from objective performance benchmarks in the form of earnings announcements and realized stock performance. Third, for the overwhelming majority of jobs leading to a top executive position, it would be impossible to quantify past performance due to both data availability and the inherent lack of easily measurable outputs. At least for part of our sample, we can accomplish this, and hence are able to compare former analyst CEO/CFOs' past performance with their current performance on related tasks. Overall, the equity research setting permits us to investigate the transfer of skill sets from past job experience, in addition to providing insights into the specific transition from equity research to a top executive position.

To identify former equity analysts, we begin with the BoardEx database from 1990 to 2017 and retrieve $\mathrm{CEO} / \mathrm{CFO}$ with prior employment listed as an 'analyst'. We narrow this to equity research analysts by manually checking for either buy-side or sell-side analyst experience with the following sources: LinkedIn, Bloomberg, Morningstar, Brokercheck, and The Wall Street Journal. Our final sample of equity analysts have, on average, six years of work experience as either a sell-side or buy-side research analyst.

Consistent with career experience in earnings forecasting, we find former analysts provide earnings guidance that is more accurate than that of other executives, controlling for standard factors that explain cross-sectional differences in guidance accuracy. In terms of economic significance, the earnings forecasts provided by former analysts are $27.2 \%$ more accurate than those of other executives. This is an important finding since management earnings forecasts are heavily relied on by market participants, explaining greater return variance than such disclosures as earnings announcements, analysts' forecasts, and SEC filings (Ball and Shivakumar 2008; Beyer, Cohen, Lys, and Walther 2010). 
Equity analysts value and recommend stocks based on fundamentals, as well as an assessment of industry growth potential and the management team (Groysberg, Healy, Nohria and Serafeim 2012). We conjecture this experience should aid CEO/CFOs in valuing an acquisition and evaluating the target's management which are critical steps in the acquisition process (Bruner and Perella 2004; DePamphilis 2019). To evaluate M\&A performance, we obtain a sample of 7,981 U.S. acquisitions. Within this sample, former analyst CEO/CFO-led acquisitions represent a total of $\$ 110$ billion in M\&A deals, comprising about $2.5 \%$ of the total deal value. We find former analyst-led acquisitions are associated with abnormal return premiums to acquisition announcements between 1.1\% and 1.2\% larger than those of other executives. In economic terms, this translates to between $\$ 133$ and $\$ 146$ million in additional shareholder value for the average former analyst-led acquirer.

For a subset of these CEO/CFOs, we can trace their forecasting and stock picking performance histories. Similar to the level of experience we observe based on our original handcollection, these analysts average 6.8 years in the IBES database. We categorize their earnings research record as 'better' if their earnings forecast accuracy record is superior to that of the median analyst; we define their stock recommendation record in the same fashion. The results indicate a positive association between a record of better earnings forecasting and more accurate current earnings guidance, as well as a positive association between better stock recommendation profitability and current M\&A success.

In addition to forecasting earnings and recommending stocks, equity analysts are frequent participants in earnings conference calls. We posit this experience should help executives prepare for earnings calls and navigate the interaction with call participants. Conference calls are an important event to investigate since they represent a significant disclosure channel for management and provide market-relevant information beyond that of earnings announcements (Bowen, Davis and Matsumoto 2002; Chen and Matsumoto 2006). Consistent with earnings call experience, we find former analyst 
executives provide greater certainty in their answers to conference call questions. This beneficial effect is economically meaningful in that executives with analyst experience provide $13.3 \%$ more certain answers than do other executives. Moreover, this effect is especially pronounced when former analyst executives are asked forward-looking questions.

Given the evidence of performance advantages in specific settings, a natural question to investigate is how former analysts' firms perform overall. This is an empirical question since better performance on these tasks-guidance, M\&A, and conference calls-certainly does not guarantee better overall firm performance. We examine annual measures of firm performance, including an accounting measure of performance (return on assets), and three- and four-factor adjusted stock return measures, finding evidence consistent with former analysts' firms exhibiting superior performance. In terms of economic impact, top executives with analyst experience generate \$64 million higher net income, on average, and improve shareholder value between $\$ 122$ and $\$ 150$ million compared to other executives.

There may be unobserved heterogeneity that explains why firms hire former analysts. For example, particular firms may prefer to hire an executive with a strong financial background. Hence, these firms might be more likely to hire a former analyst, but they also might be more likely to allocate resources to enhancing financial disclosures such as earnings guidance. Similar arguments could be made with respect to M\&A success or conference call interactions. One approach to address this concern would be to include firm-fixed effects, alleviating the concern that unobserved time-invariant factors influence our estimates. Unfortunately, we have a low number of former analyst CEO/CFOs, and this approach would force our identification strategy to rest on the even smaller number of firms that have switched from or to former analyst executives. Hence, we cannot include firm-fixed effects and arrive at reliable estimates, this is a common identification problem in studies examining top 
executive characteristics (e.g., Benmelech and Frydman 2015; Cain and McKeon 2016; Gupta, Briscoe and Hambrick 2017; Davidson, Dey and Smith 2019).

Given these limitations, what empirical strategies can we implement to address endogeneity? Aside from including industry- and year-fixed effects, along with standard firm-level control variables, we augment our main tests with two additional analyses. In the first analysis, we label firm-years as 'pseudo' former analyst executive firm-years for the years either before or after these executives take their roles, finding no significant impact on our dependent variables across analyses. Under the assumption that unmeasured firm characteristics are relatively stable — an assumption we share with the fixed-effects approach, this design can be viewed as an alternative strategy to address timeinvariant firm characteristics.

Our second approach relies on examining alternative types of career experience. Our goal is to investigate whether the former analyst experience variable is perhaps capturing a related but different form of background such as general analyst skills, financial expertise, or quantitative experience. To proxy for general analyst expertise, we identify CEO/CFOs with prior work experience as financial analysts, but not as equity research analysts. A job in this category might involve budgeting, account reconciliation, analyzing control systems, among other tasks. The key distinction between this job and that of the equity research analyst is the lack of training and experience in our focal skill sets: earnings forecasting, stock valuation, and conference call interactions. To capture executives with general financial experience, we utilize executives with prior jobs in accounting or finance, and finally, for those with a quantitative experience, we identify those with engineering backgrounds. In contrast to the equity research analyst position, we do not find evidence these alternative job categories yield positive associations with guidance accuracy, M\&A performance, or certainty in answering conference call questions. However, there is evidence $\mathrm{CEO} / \mathrm{CFO}$ s with accounting or finance backgrounds are associated with better overall firm performance. 
Our paper contributes to the broader literature in accounting and finance that examines the impact of top executives' human capital on corporate performance outcomes (e.g., Bertrand and Schoar 2003; Malmendier and Tate 2009; Bamber et al. 2010; Dyreng et al. 2010; Law and Mills 2017). Different from these studies, our interest is in whether specific forms of experience appear to carryover to top executive performance for related corporate functions. This is important for at least two reasons. First, our findings may inform market participants in general and corporate boards in particular — especially, those in need of specific expertise - that in some settings, there appears to be a transference of unique skill sets from earlier careers to top executive positions. For instance, our finding that former analyst executives provide more accurate earnings guidance should be of interest to investors and analysts, who rely on this information to form their own performance forecasts and investment strategies. Furthermore, our finding that former analyst executives lead successful M\&As should be of interest to stakeholders since M\&As represent an important but complex form of corporate investment (Moeller, Schlingemann and Stulz 2005).

Second, although there is a well-developed literature examining general career backgrounds, ultimately, individuals tend to select into certain initial careers such as military service, accounting, etc. Hence, when evaluating operational or policy outcomes, it is very difficult to disentangle the effects of the CEO/CFOs' general background experiences from their innate characteristics. Our setting focuses on a former career with aspects that are fairly standard such as forecasting, valuation, and conference call interaction. Since these skills are arguably more likely a result of on-the-job experience, it allows us to provide some evidence on the debate between the importance of experience versus inherent traits for performance outcomes (e.g., Bertrand and Schoar 2003; Adams, Keloharju, and Knupfer 2018). 


\section{RELATED LITERATURE AND DISCUSSION}

\subsection{Top executive performance outcomes}

The neo-classical view of top executive performance posits that performance outcomes are determined by firm-specific and industry factors (Bertrand and Schoar 2003). Even within a standard agency framework, individual manager behavior is largely determined by contracting and monitoring mechanisms (e.g., Alchian and Demsetz 1972; Jensen and Meckling 1976). For example, the firm can be viewed as a team-based productive effort, where required expertise or skill is contracted (Alchian Demsetz 1972). More specifically, if a CEO or CFO lacks expertise in a particular area of importance such as disclosure or acquisitions, the firm fills this void by hiring someone with the requisite expertise.

In contrast, upper echelons theory posits that organizational outcomes are, at least in part, determined by executives' individual characteristics (Hambrick and Mason 1984; Hambrick 2007). One strand of research building on this theory utilizes a fixed-effect approach to show that top executives uniquely impact corporate practices and operations. For instance, Bertrand and Schoar (2003) show managers influence a number of corporate outcomes such as investment policy, Dyreng et al. (2010) show that executives impact tax avoidance, and Ge et al. (2011) provide evidence of a significant CFO effect on financial reporting choices.

Delving into the unobserved factors behind executive effects, recent studies examine top executive heterogeneity with respect to such aspects as education, personal characteristics, and career experience. For example, in a voluntary disclosure setting, Bamber et al. (2010) find managers with backgrounds in finance, accounting, legal, and those with military experience provide more conservative disclosures. Custódio and Metzger (2013) find CEOs with backgrounds in finance or accounting hold less cash, more debt, engage in more share repurchases, and manage financial policies more actively. Law and Mills (2017) find that managers with military experience are more conservative in their tax planning strategies, as evidenced by smaller tax reserves and fewer tax havens. The 
common theme in this work is to relate general background experience to current performance outcomes. $^{2}$

Our interest differs in that we focus on specific career experiences. In particular, we are interested in whether unique skill sets carryover to top executives' performance outcomes with respect to related tasks. This focus provides opportunities for new insights. First, it may be of interest to boards in need of specific expertise to observe evidence on the transference of unique functional skill sets from earlier career experience. Second, individuals select into certain initial careers such as the military, accounting, etc. Hence, it is not entirely obvious whether effects of general experience at the $\mathrm{CEO}$ or $\mathrm{CFO}$ level are due to innate characteristics or are acquired on the job. Our setting is arguably less susceptible to this dual explanation since earnings forecasting, stock valuation, and even conference call interactions are plausibly more tightly linked to on-the-job training and experience.

\subsection{Equity analyst research experience}

The equity research analysts we consider are either former sell-side or buy-side analysts. ${ }^{3}$ Sellside and buy-side analysts' jobs overlap on many key dimensions. Both types of analysts gather information from a multitude of sources, including but not limited to SEC filings, financial press, investor days, and company visits. In addition, standard features of both jobs are forecasting performance and providing valuation judgments (Williams, Moyes and Park 1996; Cheng et al. 2006, Healy 2014; Brown, Call, Clement and Sharp 2016). ${ }^{4}$

\footnotetext{
2 The work on personality traits follows a similar structure, relating general personality characteristics to specific performance outcomes, where top executive narcissism impacts acquisitions (Aktas et al. 2016), sensation seeking shapes corporate innovation (Sunder et al. 2017), and overconfidence influences investment efficiency (Malmendier and Tate 2005).

${ }^{3}$ Empirically, we observe about $80 \%$ of our sample are former sell-side analysts.

4 The primary differences between the two sets of analysts are buy-side analysts disseminate their research internally, typically follow more companies and industries than do the sell-side, and rely on the sell-side to provide access to management (Williams et al. 1996, Cheng et al. 2006, Healy 2014, Brown et al. 2016). Important for our setting, both the buy-side and sell-side make earnings forecasts, provide stock recommendations, and participate in conference calls on a frequent basis.
} 
There is scarce empirical evidence on buy-side analysts due to the internal nature of their work (Healy 2014). However, a detailed empirical literature devoted to sell-side analysts provides a number of career experience insights relevant to our setting. For instance, sell-side analysts are adept at both collecting (Ivković and Jegadeesh 2004) and interpreting financial information (Lang and Lundholm 1996; Frankel, Kothari and Weber 2006). In addition, the quality of their research is important to them as it impacts their reputations and career outcomes (Stickel 1992; Mikhail, Walther and Willis 1999; Hong, Kubik and Solomon 2000). Studies show evidence of analyst skill acquisition in the sense that their research improves over time (Mikhail, Walther and Willis 1997; Clement 1999), and they decipher what investors perceive as important and recurring in terms of earnings (Previts, Bricker, Robinson and Young 1994; Bradshaw and Sloan 2002).

\subsection{Linking equity analyst experience to executive performance outcomes}

\subsubsection{Earnings guidance performance}

Managers' earnings forecasts are one of the most important voluntary disclosure mechanisms, reducing information asymmetry (Coller and Yohn 1997), impacting analysts' earnings expectations (Baginski and Hassell 1990; Williams 1996), and mitigating litigation concerns (Kasznik and Lev 1995; Baginski, Hassell and Kimbrough 2002). Furthermore, managers view their guidance as an important vehicle for building a reporting reputation (Graham, Harvey and Rajgopal 2005). The fundamentals of forecasting earnings as a manager or as an analyst are similar in the sense that both parties project sales growth and expense items (e.g., wages, materials, etc.) while factoring in current industry and macro-economic trends. One of the major differences is that managers have direct access to disaggregated financial and non-financial information. At first blush, it may seem that CFOs are better positioned to impact the quality of earnings guidance due to their direct involvement in the financial reporting process. However, it is important to note that CEOs have an important 'top-down' influence on earnings guidance by prioritizing disclosure quality, evaluating the economic outlook, and having 
the final decision on issuance (e.g., Aboody and Kasznik 2000; Baik, Farber, and Lee 2011; Cassell et al. 2013). ${ }^{5}$

\subsection{2. $\quad M \& A$ performance}

Analysts form valuations based on qualitative inputs, as well as multiples such as price-toearnings ratio and multi-period DCF models (Demirakos et al. 2004). Since analysts forecast earnings, they have readily available inputs to either multiples or models, and there is evidence of this link in the sense that analysts who issue more accurate forecasts also issue more profitable stock recommendations (Loh and Mian 2006; Ertimur, Sunder and Sunder 2007). Ultimately, analysts' quantitative inputs are combined with an assessment of industry growth potential and the quality of the management team to form an overall valuation judgement (Groysberg, Healy, Nohria and Serafeim 2012). This same combination of a valuation exercise and an assessment of industry and management is central to properly pricing an acquisition which is a critical step in the acquisition process (Bruner and Perella 2004; DePamphilis 2019).

\section{DATA SOURCES AND KEY VARIABLES}

\subsection{Financial data}

We gather management earnings forecasts between 1993 and 2016 from the Institutional Brokers' Estimate System (IBES) database. To avoid pre-announcements, we focus on management annual earnings forecasts issued prior to the end of the fiscal years for which forecasts are made. When there are multiple forecasts available for the same fiscal year, we keep the last forecast. We obtain M\&A deals from the Securities Data Corporation (SDC) Platinum Mergers and Acquisitions database for the period 1993 to 2016. Following prior literature, we require the acquirers to be U.S. firms and

\footnotetext{
${ }^{5}$ Beyond the ability to contract for disclosure expertise, there are additional reasons why CEO/CFOs with analyst experience may not yield disclosure quality that differs from that of other executives. First, managers may not forecast as fully or precisely as possible due to proprietary costs (e.g., Wang 2007; Bamber and Cheon 1998). Second, managers may strategically bias their voluntary earnings guidance to walk-down earnings benchmarks (Bergman and Roychowdhury 2007; Cotter, Tuna and Wysocki 2006) or due to equity incentives (Aboody and Kasznik 2000; Cheng and Lo 2006).
} 
the minimum deal value to be $\$ 1$ million (Cai and Sevilir 2012). Our conference call sample, obtained from Bushee et al. (2018), covers the period 2002 through 2015. All other financial variables are from the Compustat and CRSP databases.

\subsection{Former equity research analyst experience}

We manually identify executives who have equity research analyst experience as either sell-side or buy-side analysts. Specifically, we begin with the Individual Profile Employment dataset of the BoardEx database to obtain the names of public companies' CEO/CFOs and their director IDs from 1990 to 2017. The database provides a variable RoleName to describe job titles and a variable FulltextDescription describing job responsibilities in detail. We search key words 'chief executive officer', 'CEO', 'chief finance officer', 'chief financial officer', or 'CFO' in these two variables to identify CEO/CFOs. Next, we use director IDs to obtain their previous employment records in BoardEx. To identify prior work experience as equity research analysts, we search keywords such as 'analyst', 'equity research', and 'research associate' in the job title and description variables. Since these keywords may be related to analysts in other job categories (e.g., marketing analysts), we verify equity research analyst experience with one or more of the following additional sources: LinkedIn, Bloomberg, Morningstar, Brokercheck, and The Wall Street Journal. Our variable of interest is Former Analyst, which takes a value of one if a firm's $\mathrm{CEO} / \mathrm{CFO}$ in a given fiscal year has prior work experience as an equity research analyst and zero otherwise. A point we wish to emphasize: across our regressions, the benchmark for the former analyst executives (the zeros) is comprised firms which do not have a CEO/CFO with research analyst experience but have the option, either exercised or not, to hire or contract for requisite experience in disclosure, acquisitions, and investor communications.

Table 1 provides summary statistics for the former analyst CEO/CFOs in our main tests. After merging with necessary financial data for our analyses, our sample observations of CEO/CFOs with analyst experience in terms of firm-years (unique former analysts) are as follows: accuracy and 
relative accuracy tests 203 (64) and 160 (54), respectively; M\&A performance tests 116 (33); conference call tests 852 (60); and ROA performance 181 (55) and equity return performance 191 (61). Although these sample sizes are not large, they are in line with prior work investigating a focused sample of CEO background characteristics (e.g., Davidson et al. 2015; Neyland 2016; Sunder et al. 2017). ${ }^{6}$

\section{RESEARCH DESIGN AND RESULTS}

\subsection{Management earnings forecast accuracy}

\section{Model specification and descriptive statistics}

We capture the accuracy of management earnings forecasts with two approaches. First, we measure Accuracy as the absolute value of management forecast error multiplied by (-1). The error is defined as forecasted EPS (point or midpoint of the range forecast) minus actual EPS, divided by logged assets per share.

Second, we evaluate a relative accuracy measure, Relative Accuracy, which benchmarks management forecast errors to that of the trailing analyst consensus. Specifically, relative accuracy is the absolute difference between the median analyst forecast in the 60 days before the management forecast and the actual EPS minus the absolute difference between the management forecast and the actual EPS, divided by the absolute difference between the median analyst forecast in 60 days before the management forecast and the actual EPS.

$\begin{aligned} & \text { Relative } \\ & \text { Accuracy }\end{aligned} \quad=\frac{\text { Abs(median analyst forecast - actual EPS) - Abs(management forecast - actual EPS) }}{\text { Abs(median analyst forecast - actual EPS) }}$

Following prior studies (Ajinkya, Bhojraj and Sengupta 2005; Cassell, Huang and Sanchez 2013), we control for a broad set of variables, including firm size (Size), analyst following (Analyst Following), industry litigation risk (Litigate), book-to-market ratio $(B / M)$, companies with negative earnings (Loss),

\footnotetext{
${ }^{6}$ Specifically, Davidson et al. (2015) identify 27 CEOs with legal records, Neyland (2016) examines 79 CEOs with divorces, and Sunder et al. (2017) identify 88 CEOs who are airplane pilots.
} 
the number of days between the forecast date and the fiscal period end (Horizon), analysts' earnings forecast disagreement (Analyst Dispersion), whether current quarter earnings are higher than that of the same quarter in last year (News), earnings volatility over the past five years (Earnings Volatility), equity beta (Beta), the post-Regulation FD period (Reg FD), stock return performance (Return), monthly stock return volatility during the fiscal year (Return Volatility), and industry competition (HHI). Appendix B provides detailed variable definitions.

We estimate the impact of prior analyst working experience on management forecast accuracy using the following OLS regression models, where indexes for firm and year are omitted for brevity:

$$
\begin{aligned}
& \text { Accuracy }=\alpha_{0}+\alpha_{1} \cdot \text { Former Analyst }+ \text { Firm Controls }+ \text { Industry Effects } \\
& + \text { Year Effects }+\varepsilon_{1} \\
& \text { Relative } \quad=\beta_{0}+\beta_{1} \cdot \text { Former Analyst }+ \text { Firm Controls }+ \text { Industry Effects } \\
& \text { Accuracy }+ \text { Year Effects }+\varepsilon_{2}
\end{aligned}
$$

A positive (negative) coefficient estimate on Former Analyst indicates that former analyst executives provide earnings guidance that is more (less) accurate than that of other executives. For all regressions in this study, continuous variables are winsorized at the top and bottom 1 percentiles, and the t-statistics are clustered by firm and year to address cross-sectional and time-series dependence (Gow, Ormazabal and Taylor 2010).

Table 2, Panel A provides descriptive statistics of the variables used in our regression analysis involving management forecasts. The median value of Relative Accuracy is 0.273 , suggesting that analyst forecast errors are greater than management forecast errors for the majority of the sample firms. That is, management forecasts, in general, are more accurate than analyst forecasts. The mean and median values of Accuracy are -0.089 and -0.019, respectively. 


\section{Multivariate results}

Table 3 reports the OLS regressions results of Equation (1). In Column (1) where the dependent variable is Accuracy, we find that the coefficient estimate on Former Analyst is positive (0.024) and statistically significant at the 5\% level, indicating former analyst executives provide more accurate management forecasts than other executives. In terms of economic significance, the result indicates that earnings forecasts provided by executives with prior analyst working experience are $27.2 \%$ more accurate than the forecast accuracy of the average guidance in our sample. ${ }^{7}$

Turning to our control variables, the coefficient estimates are generally consistent with prior empirical work. Specifically, management forecast accuracy is positively related to stock returns (Return), analyst coverage (Analyst Following) and positive earnings surprises (News), indicating that good firm performance and analyst monitoring increase managers' willingness to issue accurate management forecasts. Consistent with Ajinkya et al. (2005), we find that managers provide more accurate forecasts when there is considerable disagreement among analysts (Analyst Dispersion). We also document a negative association between management forecast accuracy and earnings uncertainty (Earnings Volatility) and negative firm performance (Loss). Finally, the coefficient on firm size (Size) is significantly negative, which is possibly due to collinearity as there are many other variables such as analyst following also capturing firm size. To investigate further, we compute the Pearson correlation coefficient between firm size and management forecast accuracy and find the correlation to be significantly positive (0.148), suggesting larger firms have more accurate management forecasts.

\footnotetext{
${ }^{7}$ Calculated as the average increase in accuracy by former analysts divided by the absolute mean of accuracy in the sample $=0.0242 /|-0.089|=27.19 \%$.
} 
Column (2) presents the regression results in which the dependent variable is Relative Accuracy. Consistent with the results in Column (1), we find the coefficient on Former Analyst to be positive (0.218) and statistically significant at the 5\% level. This finding indicates that forecasts made by former analyst executives are more accurate than other executives within a design that directly controls for firm-period effects.

\subsection{Merger and acquisition performance}

\section{Model specification and descriptive statistics}

We examine M\&A performance by regressing the short-window return, Performance, associated with the acquisition announcement on our variable of interest, Former Analyst, and control variables. Following prior literature on M\&A performance (e.g., Cai and Sevilir 2012; Masulis, Wang and Xie 2007), we measure Performance as either the cumulative or buy-and-hold abnormal returns in the fiveday event window $(-2,+2)$ centered on the M\&A announcement date. The abnormal returns are calculated based on either the Fama and French (1993) three-factor model or the Carhart (1997) fourfactor model and estimated over the 200 trading days ending two months before the M\&A announcement. As Cai and Sevilir (2012) note, this choice of the estimation period minimizes potential bias in M\&A performance due to investor anticipation or information leakage before the M\&A announcement date.

Following Cai and Sevilir (2012) and Huang, Jiang, Lie and Yang (2014), we include acquirer characteristics, target characteristics and deal characteristics as control variables for M\&A performance. Acquirer characteristics include the book-to-market ratio $(B / M)$, firm size $(\log$ total assets), Tobin's $Q$, return on assets $(\mathrm{ROA})$, Sales Growth, total liabilities scaled by assets (Leverage), and returns over the 200-day trailing period (Stock Price Run-Up). We also control for target characteristics 
including whether the target is a public firm (Public Target) and whether it is a domestic firm (Domestic Target). Relevant deal characteristics include the deal value relative to the acquirer's market value (Relative Deal Size), as well as indicators for the existence of greater than $5 \%$ pre-acquisition ownership by the acquirer (Toebold), Competing Offer, 100\% stock deals (Stock Deal), 100\% cash deals (Cash Deal), diversifying acquisitions (Diversifying Acquisition), tender offers (Tender Offer), and hostile takeovers (Hostile). Appendix B provides detailed variable definitions.

Based on the preceding discussion, we estimate the following OLS regression model, where indexes for firm and year are omitted for brevity:

$$
\begin{aligned}
\text { Performance }=\quad \gamma_{0} & +\gamma_{1} \cdot \text { Former Analyst }+ \text { Acquirer Controls }+ \text { Target Controls } \\
& + \text { Deal Controls }+ \text { Industry Effects }+ \text { Year Effects }+\varepsilon_{3}
\end{aligned}
$$

A positive (negative) coefficient estimate on Former Analyst indicates that acquiring firms led by former analyst executives experience higher (lower) returns during M\&A announcements than those of other executives.

Table 2, Panel B presents descriptive statistics of variables used in the M\&A tests. The median cumulative or buy-and-hold abnormal returns during the 5-day M\&A announcement window range between 0.003 and 0.004 . Among M\&As made by our sample firms, $18.9 \%$ of deals involve public targets and $85.6 \%$ of deals involve domestic targets. In terms of financing methods, only $6.9 \%$ of M\&A transactions use only equity financing, while $41.8 \%$ of M\&As use only cash financing.

\section{Multivariate results}

Table 4 reports the OLS regression results. After controlling for standard firm, target and deal characteristics, we find that acquirers whose $\mathrm{CEO} / \mathrm{CFO}$ s have prior analyst working experience are associated with announcement returns that range between $1.07 \%$ and $1.18 \%$ higher than those of 
other executives. ${ }^{8}$ This result is consistent with our contention that stock picking and valuations skills developed at an earlier career stage helps executives better identify and value acquisition targets, resulting in more successful acquisitions. In economic terms, the effect translates to an increase in shareholder value ranging between $\$ 132.7$ and $\$ 146.3$ million for the average former analyst-led acquirer in our sample. ${ }^{9}$

The coefficient estimates on the control variables are generally consistent with prior literature. Similar to Moeller et al. (2005) and Masulis et al. (2007), we find acquirer size and stock price run-up are negatively associated with announcement returns, while acquirer leverage and deal size relative to the size of the acquirer are positively associated with announcement returns. In line with the findings in Huang et al. (2014), we find acquisitions involving cash financing or tender offers experience higher announcement returns, whereas acquisitions in which acquirers possesses a toehold in targets and acquisitions involving public targets, diversifying investments, and competing offers are associated with lower announcement returns.

\subsection{Former analyst CEO/CFOs earnings guidance accuracy and M\&A performance: Cross-sectional evidence from past performance}

The preceding analyses relies on the assumption that former equity analysts gained skills in earnings forecasting and stock valuation, later applying these skills to the related tasks of providing management earnings forecasts and valuing M\&A targets. Since the former analysts in our sample

\footnotetext{
${ }^{8}$ Although short-window announcement returns are commonly used in the literature to evaluate the quality of M\&As, we also examine one-year cumulative and buy-and-hold abnormal returns during the post-acquisition period to proxy for the M\&A quality. In untabulated tests, we continue to find acquirers whose CEO/CFOs have prior analyst working experience are associated with higher one-year cumulative and buy-and-hold abnormal returns.

${ }^{9}$ Calculated as the mean of acquirers' market capitalization multiplied by the average increase in stock returns: $\$ 12.4$ billion

$* 1.07 \%=\$ 132.68$ million and $\$ 12.4$ billion $* 1.18 \%=\$ 146.32$ million.
} 
have an average of 6.8 years of experience as equity analysts, this seems like a reasonable assumption. However, to tighten this link, we examine whether former analysts who were better at earnings forecasting or stock selection are associated with more accurate earnings guidance or more successful M\&A, respectively.

We begin by matching our sample of former analyst CEO/CFOs to the IBES database. This is a tedious process which we outline in detail in Appendix A. The end result is that we are able to assemble earnings forecasting performance records for 18 unique analysts (representing 40 analyst firm-years) for use in a guidance accuracy analysis, and we assemble stock recommendation performance records for 9 unique analysts (representing 33 firm-years) for an M\&A analysis.

In the accuracy model, we evaluate Relative Accuracy since it directly controls for firm-period effects, and replace the Former Analyst variable with better and worse former analyst earnings forecasters. We define Better (Worse) Forecaster as equal to one if the CEO/CFO is a former analyst and had better (worse) forecast ability as an analyst, where forecast ability is defined as better (worse) if past relative forecast accuracy is higher (lower) than the median IBES analyst in our sample and equal to zero otherwise.

We modify the M\&A performance model in a similar fashion by replacing Former Analyst with better and worse former analyst stock recommenders. We define Better (Worse) Recommender as equal to one if the $\mathrm{CEO} / \mathrm{CFO}$ is a former analyst and had better (worse) recommendation profitability, where recommendation profitability is identified as better (worse) if past recommendation profitability is higher (lower) than the median IBES analyst in our sample and equal to zero otherwise. Recommendation profitability is measured as the one-year market-adjusted returns following an analyst's strong buy or buy recommendation, or one-year returns times (-1) following an analyst's underperform or sell recommendation. 
Based on the preceding discussion, we specify the following OLS regression models, where indexes for firm and year are omitted for brevity:

Relative $\quad=\delta_{0}+\delta_{1} \cdot$ Better forecaster $+\delta_{2} \cdot$ Worse forecaster + Firm Controls

Accuracy Industry Effects + Year Effects $+\varepsilon_{4}$

Performance $=\lambda_{0}+\lambda_{1} \cdot$ Better recommender $+\lambda_{2} \cdot$ Worse recommender + Acquirer Controls

$$
+ \text { Target Controls }+ \text { Deal Controls }+ \text { Industry Effects }+ \text { Year Effects }+\varepsilon_{5}
$$

We expect positive coefficient estimates on the Better Forecaster and Better Recommender variables; however, the estimates on the Worse Forecaster and Worse Recommender variables are an empirical question since it may be below-median analysts are sufficiently skilled in forecasting and stock valuation to provide benefits to their earnings guidance and M\&A performance, respectively.

\section{Multivariate results}

Table 5 reports the results of the OLS regressions. Consistent with our expectations, we find the coefficient on Better Forecaster is positive (0.515) and statistically significant at the $5 \%$ level. While Worse Forecaster is also positively associated with Relative Accuracy, it is not statistically significant at conventional levels. Similarly, we document a significant positive association between Better Recommender and acquisition announcement returns, while Worse Recommender does not appear to have a significant effect on announcement returns. Together, the results indicate that CEOs/CFOs who are better skilled former analysts have superior performance in forecasting earnings and leading successful acquisitions. This, in turn, is consistent with our contention that earnings forecasting and stock picking skills developed at an early career stage play an important role in management forecasts and M\&As. 


\subsection{Earnings conference call interactions}

Beyond forecasting earnings and recommending stocks, analysts frequently participate in conference calls where they interact with management during the Q\&A sessions. Analysts view these calls as important since these interactions provide them with public information that can complement their private information sets (Mayew 2008; Chen and Matsumoto 2006). For executives, conference calls are important as well, providing an important corporate disclosure channel which allows CEOs and CFOs to efficiently communicate with large numbers of analysts and portfolio managers (Frankel, Johnson and Skinner 1999). We conjecture that conference call experience acquired as an equity analyst should help executives anticipate and prepare for questions, resulting in more certainty in their answers.

\section{Model specification}

We evaluate former analyst executives' conference call interactions by regressing Managerial Answer Certainty on our variable of interest, Former Analyst, and control variables for firm growth, size, stock returns, stock uncertainty, earnings uncertainty and analyst uncertainty (i.e., $B / M$, Size, Return, Return Volatility, Earnings Volatility, and Analyst Dispersion). The dependent variable Managerial Answer Certainty is the percentage of words in a CEO/CFO's answers to analyst questions during a conference call that make answers more uncertain multiplied by -100 . The 'uncertain' direction of the coding originates with Loughran and McDonald (2011), which we transform to ease the discussion of the results (i.e., managers are 'more certain' as opposed to 'less uncertain'). Answers providing greater certainty with respect to firm performance are particularly important when analysts are seeking forward-looking information. Hence, we identify forward-looking questions asked by analysts, ForwardLooking Questions, based on Li (2010). In cross-sectional tests, we interact quintile rank and indicator versions of the Forward-Looking Questions variable with Former Analyst to examine whether the 
$\mathrm{CEO} / \mathrm{CFO}$ with prior analyst experience provide more certain answers when being asked forwardlooking questions by analysts.

Based on the preceding discussion, we specify the following OLS regression model, where indexes for firm and year are omitted for brevity:

Managerial $=\theta_{0}+\theta_{1} \cdot$ Former Analyst $+\theta_{2} \cdot$ Forward-Looking Questions

Answer $\quad+\theta_{3} \cdot$ Former Analyst $\cdot$ Forward-Looking Questions + Firm Controls

Certainty + Industry Effects + Year Effects $+\boldsymbol{\varepsilon}_{7}$

A positive (negative) coefficient estimate on Former Analyst indicates that former analyst executives provide answers that are more (less) certain than that of other executives. A positive (negative) coefficient estimate on the interaction Former Analyst · Forward-Looking Questions indicates that former analyst executives provide answers to forward-looking questions that are more (less) certain than that of other executives.

\section{Multivariate results}

Table 6 reports the OLS regression results. We find that former analyst executives provide greater certainty in their answers to analyst questions during conference calls as evidenced by a significant and positive coefficient estimate on the Former Analyst variable (0.046) in Column (1). This effect is economically significant as well. Specifically, executives with former equity research experience provide $13.3 \%$ greater certainty when answering analysts' questions than do other executives, after controlling for determinants of the managerial certainty. ${ }^{10}$ In the second column, the coefficient estimate on the interaction between Former Analyst and the quintile Forward-Looking Questions is significantly positive (0.0103), while the estimate on the lower-order term Former Analyst is insignificant. The combined finding implies that the certainty effect is important only when there is some degree

$1013.34 \%$ is equal to the coefficient estimate 0.0461 divided by the absolute mean value of the managerial certainty variable 0.3455 . 
of forward-looking nature to analysts' questions. In the third column, the coefficient estimate on the interaction term between Former Analyst and the top quintile Forward-Looking Questions is significantly positive (0.0260) and the estimate on the lower-order term Former Analyst is also significant and positive (0.0408), implying former analyst executives provide even greater certainty when faced with the most forward-looking questions.

\subsection{Overall firm performance}

\section{Model specification}

Although former analyst executives appear able at tasks such as providing earnings guidance, M\&A, and conference call participation, it is an open question whether their firms perform well overall. To answer this question, we examine firm performance by regressing Firm Performance on our variable of interest, Former Analyst, and control variables. Specifically, we use two types of performance variables to measure Firm Performance. The first one is return on assets, $\mathrm{R} O A$, which is net income divided by total assets. The second type is stock return performance based on either cumulative or buy-and-hold abnormal returns over the fiscal year performance window. The abnormal returns are calculated using either the Fama and French (1993) three-factor model or Carhart (1997) four-factor model estimated over the 150 trading days ending 15 days before the fiscal year starts. We require a minimum of 90 non-missing daily returns in the estimation window.

Based on prior studies evaluating firm performance (e.g., Anderson and Reeb 2003), we control for firm size (Size), stock return volatility (Return Volatility), research and development expense dummy $(R \odot D)$, and firm age (Age). In addition, we control for recent earnings volatility (Earnings Volatility), analyst following (Analyst Following), the legal environment of the industry (Litigate), bookto-market ratio $(B / M)$, analysts' earnings forecast disagreement (Analyst Dispersion), and industry competition (HHI). Detailed variable definitions can be found in Appendix B. 
Based on the preceding discussion, we specify the following OLS regression model, where indexes for firm and year are omitted for brevity:

Firm $\quad=\quad \xi_{0}+\xi_{1} \cdot$ Former Analyst + Firm Controls + Industry Effects

Performance + Year Effects $+\boldsymbol{\varepsilon}_{6}$

Based on our definitions of Firm Performance, a positive (negative) coefficient estimate on Former Analyst indicates that former analyst executives' firms perform better (worse) than those of other executives. Table 2, Panel C provides descriptive statistics of variables used in the overall firm performance tests. The median value of ROA is 0.045 , suggesting that our sample firms are profitable in the majority of our firm-years.

\section{Multivariate results}

Table 7 reports the results of OLS regressions. We find that firm-years with former analyst $\mathrm{CEO} / \mathrm{CFOs}$ are associated with 3.94\% higher ROA and stock returns that range between $7.78 \%$ and 9.55\% higher than those of other executives. In economic terms, this translates to a $\$ 64$ million increase in net income on average, and between $\$ 122$ and $\$ 150$ million in additional shareholder value. ${ }^{11}$ Overall, the findings suggest that former analyst executives not only perform better at specific tasks_-such as guidance, M\&A, and conference call interactions-but also their firms exhibit better overall performance.

\subsection{Unobserved heterogeneity and former analyst CEO/CFO results}

\section{Discussion and research design}

There may be unobserved heterogeneity that explains why firms hire former analysts. A familiar approach to address this issue is to include firm-fixed effects, addressing the concern over

\footnotetext{
11 The increase in net income is calculated as the average increase in ROA multiplied by the median total assets: $3.94 \%$ * $\$ 1623.64$ million $=\$ 63.97$ million. The increase in shareholder value is calculated as the average increase in stock returns multiplied by the median market capitalization in the firm performance sample: $7.78 \% * \$ 1573.24$ million $=\$ 122.40$ million and $9.55 \% * \$ 1573.24$ million $=\$ 150.24$ million.
} 
unobserved time-invariant factors which may confound our estimates. Since we have a limited sample of former analyst $\mathrm{CEO} / \mathrm{CFOs}$, this approach would force our identification strategy to rest on the even smaller number of firms both with and without former analysts in the CEO/CFO roles. Hence, we cannot include firm-fixed effects and derive reliable estimates.

To mitigate concerns that our results are a manifestation of unobserved heterogeneity, we offer two forms of placebo tests. In the first test, we label observations as 'pseudo-former analyst' firm-years during the period of time before and after former analyst CEO/CFOs assume their executive roles. For example, a management earnings forecast announced in the year prior to the actual tenure of the former analyst $\mathrm{CEO} / \mathrm{CFO}$ or after the executive's last year in office is regarded as issued by a pseudo-former analyst and is assigned a value of one. We re-examine each of our findings with this pseudo-former analyst approach. If the results we obtain are manifestations of time-invariant firm effects, we are likely to find similar results for pseudo-former analysts as well.

In the second test, we examine several types of alternative work experience. The objective is to examine whether former analyst experience is picking up related types of career experiences that might also be associated with our dependent variables of interest. In particular, we examine general analyst skills, financial expertise, and quantitative experience. To proxy for general analyst expertise, we identify $\mathrm{CEO} / \mathrm{CFOs}$ with prior work experience as a financial analyst, but not as an equity research analyst. The distinction between this job and that of the equity research analyst is the lack of training and experience in our focal job traits: earnings forecasting, stock selection, and conference call interactions.

To proxy for financial expertise, we utilize executives with prior experience in accounting or finance. The accounting and finance work experience includes positions such as financial compliance, financial assurance, accountant, controller, and bookkeeper. Finally, to proxy for a quantitative 
background, we identify those with engineering experience, where examples of positions include software engineers, civil engineers, facilities engineers, and engineering technicians.

\section{Multivariate results}

Table 8, Column 1 shows the results for the pseudo-former analyst executive approach. The coefficient estimates on pseudo-former analyst executives are insignificant across all the tests, providing evidence that our results are unlikely to be subject to unobservable time-invariant firm characteristics. Columns 2 to 4 of Table 8 present the results for CEO/CFOs with general financial analyst, accounting/finance, and engineering experience, respectively. The coefficient estimates on these alternative working experience variables are not significant at conventional levels for the specific tests surrounding guidance accuracy, M\&A performance, and certainty in answering conference call questions. ${ }^{12}$ However, there is evidence $\mathrm{CEO} / \mathrm{CFO}$ s with accounting/finance backgrounds are associated with better overall firm performance. Overall, these two approaches help validate the positive associations we find between executives' previous equity analyst experience and guidance accuracy, M\&A performance, certainty in answering conference call questions, and firm performance.

\section{CONCLUSION}

Prior work has shown $\mathrm{CEO}$ and $\mathrm{CFO}$ fixed-effects uniquely impact corporate practices and operations. Delving into these effects, recent studies examine general executive traits such as education, personal characteristics, and career experience. In contrast, our interest is in specific experience, and whether such experience carries over to top executive performance on related tasks. We assemble a sample of CEO/CFOs who have prior work experience as equity research analysts. We find these former analyst executives provide earnings guidance that is more accurate than that of other executives. In fact, our evidence indicates that earnings forecasts provided by former analysts are $27.2 \%$ more

\footnotetext{
12 The lack of statistical significance in these tests is not likely due to small samples sizes as these job categories provide larger samples than our category of interest, former research analysts.
} 
accurate than other executives. Moreover, we find former analyst-led acquisitions are associated with abnormal return premiums to acquisition announcements between $1.1 \%$ and $1.2 \%$ larger than those of other executives. In economic terms, this translates to between $\$ 132.7$ million and $\$ 146.3$ million in additional shareholder value.

For a subset of $\mathrm{CEO} / \mathrm{CFOs}$, we trace their forecasting and stock picking performance histories. The results indicate a positive association between a record of better earnings forecasting and more accurate current earnings guidance, as well as a positive association between better stock recommendation profitability and current M\&A success.

In addition to forecasting earnings and picking stocks, equity analysts are frequent participants in earnings conference calls. We posit that this type of experience should help executives prepare for earnings calls and generally navigate the conference call interactions. Consistent with earnings call experience, we find executives with analyst experience provide $13.3 \%$ more certain answers than do other executives.

Given the evidence of several specific performance advantages, a natural question to investigate is how former analysts' firms perform overall. We examine annual measures of firm performance, including an accounting measure of performance, return on assets (ROA), and stock return measures, finding consistent evidence that former analysts' firms exhibit superior performance. In terms of economic impact, executives with analyst experience generate $\$ 64$ million higher net income on average and improve shareholder value between $\$ 427$ and $\$ 524$ million compared to other executives.

Our paper contributes to the broader literature in accounting and finance that examines the impact of top executives' human capital on corporate performance outcomes. Different from these studies, our interest is in whether specific forms of experience carryover to top executive performance. This is important for at least two reasons. First, our findings may inform market participants in general 
and corporate boards in particular that at least in some settings, there appears to be a transference of unique skill sets from earlier careers to top executive positions. Second, although there is a welldeveloped literature examining general career backgrounds, ultimately, individuals tend to select into certain initial careers. Hence, when evaluating operational or policy outcomes, it is very difficult to disentangle the effects of the CEO/CFO's general background from the innate characteristics which, in part, placed them on a particular career path. In contrast, our setting focuses on specific skills that are part of on-the-job experience, resulting in evidence that is arguably less likely driven by inherent traits. 


\section{REFERENCES}

Aboody, D. and R. Kasznik. 2000. CEO Stock Option Awards and the Timing of Corporate Voluntary Disclosures. Journal of Accounting and Economics 29: 73-100.

Adams, R., M. Keloharju, and S. Knupfer. 2018. Are CEOs Born Leaders? Lessons from Traits of a Million Individuals. Journal of Financial Economics 130: 392-408.

Ajinkya, B., S. Bhojraj, and P. Sengupta. 2005. The Association between Outside Directors, Institutional Investors and the Properties of Management Earnings Forecasts. Journal of Accounting Research 43 (3): 343-376.

Aktas, N., E. de Bodt, H. Bollaert, and R. Roll. 2016. CEO Narcissism and the Takeover Process: From Private Initiation to Deal Completion. Journal of Financial and Quantitative Analysis 51 (1): 113-137.

Alchian, A. and H. Demsetz. 1972. Production, Information Costs, and Economic Organization,” American Economic Review 66: 777-795

Anderson, R. and D. Reeb. 2003. Founding-Family Ownership and Firm Performance: Evidence from the S\&P 500. The Journal of Finance 58 (3): 1301-1328.

Baik, B., D. Farber, and S. Lee. 2011. CEO Ability and Management Earnings Forecasts. Contemporary Accounting Research 28: 1645-1668.

Baginski, S. and J. Hassell. 1990. The Market Interpretation of Management Earnings Forecasts as a Predictor of Subsequent Financial Analyst Forecast Revision. The Accounting Review 65 (1): 175190.

Baginski, S., J. Hassell, and M. Kimbrough. 2002. The Effect of Legal Environment on Voluntary Disclosure: Evidence from Management Earnings Forecasts Issued in U.S. and Canadian Markets. The Accounting Review 77 (1): 25-50.

Ball, R., and L. Shivakumar. 2008. How much new information is there in earnings? Journal of Accounting Research 46: 975-1016.

Bamber, L. and Y. Cheon. 1998. Discretionary Management Earnings Forecast Disclosures: Antecedents and Outcomes Associated with Forecast Venue and Forecast Specificity Choices. Journal of Accounting Research 36 (2): 167-190.

Bamber, L., J. (Xuefeng) Jiang, and I. Wang. 2010. What's My Style? The Influence of Top Managers on Voluntary Corporate Financial Disclosure. The Accounting Review 85 (4): 1131-1162.

Benmelech, E., and C. Frydman. 2015. Military CEOs. Journal of Financial Economics 117 (1): 43-59.

Bergman, N. and S. Roychowdhury. 2007. Investor Sentiment, Expectations, and Corporate Disclosure. Working Paper.

Bertrand, M., and A. Schoar. 2003. Managing with Style: The Effect of Managers on Firm Policies. The Quarterly Journal of Economics 118 (4): 1169-1208.

Beyer, A., D. Cohen, T. Lys, and B. Walther. 2010. The Financial Reporting Environment: Review of the Recent Literature. Journal of Accounting and Economics 50: 296-343.

Bowen, R. M., A. K. Davis, and D. A. Matsumoto. 2002. Do Conference Calls Affect Analysts' Forecasts? The Accounting Review 77 (2): 285-316.

Bradshaw, M. T., and R. G. Sloan. 2002. GAAP versus The Street: An Empirical Assessment of Two Alternative Definitions of Earnings. Journal of Accounting Research 40 (1): 41-66.

Brown, L., A. Call, M. Clement, and N. Sharp. 2016. The Activities of Buy-Side Analysts and the Determinants of Their Stock Recommendations. Journal of Accounting and Economics 62 (1): 139_ 156.

Bruner, R. and J. Perella. 2004. Applied Mergers and Acquisitions. John Wiley \& Sons. 
Bushee, B., I. Gow, and D. Taylor. 2018. Linguistic Complexity in Firm Disclosures: Obfuscation or Information? Journal of Accounting Research 56 (1): 85-121.

Cai, Y., and M. Sevilir. 2012. Board Connections and M\&A Transactions. Journal of Financial Economics 103 (2): 327-349.

Cain, M. and S. McKeon. 2016. CEO Personal Risk-Taking and Corporate Policies. Journal of Financial and Quantitative Analysis 51 (1): 139-164.

Carhart, M. 1997. On Persistence in Mutual Fund Performance. The Journal of Finance 52 (1): 57-82.

Cassell, C., S. Huang, and J. Sanchez. 2013. Forecasting without Consequence? Evidence on the Properties of Retiring CEOs' Forecasts of Future Earnings. The Accounting Review 88 (6): 1909_ 1937.

Chen, S., and D. Matsumoto. 2006. Favorable versus Unfavorable Recommendations: The Impact on Analyst Access to Management-Provided Information. Journal of Accounting Research 44 (4): 657-689.

Cheng, Y., M. Liu, and J. Qian. 2006. Buy-Side Analysts, Sell-Side Analysts, and Investment Decisions of Money Managers. Journal of Financial and Quantitative Analysis 41 (1): 51-83.

Cheng, Q. and K. Lo. 2006. Insider Trading and Voluntary Disclosures. Journal of Accounting Research 44: 815-848.

Clement, M. 1999. Analyst forecast accuracy: Do Ability, Resources, and Portfolio Complexity Matter? Journal of Accounting and Economics 27 (3): 285-303.

Coller, M., and T. Yohn. 1997. Management Forecasts and Information Asymmetry: An Examination of Bid-Ask Spreads. Journal of Accounting Research 35 (2): 181-191.

Cotter, J., I. Tuna, and P. Wysocki. 2006. Expectations Management and Beatable Targets: How Do Analysts React to Explicit Earnings Guidance? Contemporary Accounting Research 23 (3): 593624.

Custódio, C., and D. Metzger. 2013. How Do CEOs Matter? The Effect of Industry Expertise on Acquisition Returns. The Review of Financial Studies 26 (8): 2008-2047.

Davidson, R., A. Dey, and A. Smith. 2015. Executives' "Off-the-Job” Behavior, Corporate Culture, and Financial Reporting Risk. Journal of Financial Economics 117 (1): 5-28.

Davidson, R., A. Dey, and A. J. Smith. 2019. CEO Materialism and Corporate Social Responsibility. The Accounting Review 94 (1): 101-126.

Demirakos, E., N. Strong, and M. Walker. 2004. What Valuation Models Do Analysts Use? Accounting Horizons 18 (4): 221-240.

DePamphilis, D. 2019. Mergers, Acquisitions, and Other Restructuring Activities: An Integrated Approach to Process, Tools, Cases, and Solutions, $10^{\text {th }}$ Edition. Academic Press.

Dyreng, S. D., M. Hanlon, and E. L. Maydew. 2010. The Effects of Executives on Corporate Tax Avoidance. The Accounting Review 85 (4): 1163-1189.

Ertimur, Y., J. Sunder, and S. Sunder. 2007. Measure for Measure: The Relation between Forecast Accuracy and Recommendation Profitability of Analysts. Journal of Accounting Research 45 (3): 567-606.

Fama, E., and K. French. 1993. Common Risk Factors in the Returns on Stocks and Bonds. Journal of Financial Economics 33 (1): 3-56.

Frankel, R., M. Johnson, and D. Skinner. 1999. An Empirical Examination of Conference Calls as a Voluntary Disclosure Medium. Journal of Accounting Research 37 (1): 133-150.

Frankel, R., S. P. Kothari, and J. Weber. 2006. Determinants of the Informativeness of Analyst Research. Journal of Accounting and Economics 41 (1): 29-54. 
Ge, W., D. Matsumoto, and J. Zhang. 2011. Do CFOs Have Style? An Empirical Investigation of the Effect of Individual CFOs on Accounting Practices. Contemporary Accounting Research 28 (4): 1141-1179.

Gow, I., G. Ormazabal, and D. Taylor. 2010. Correcting for Cross-Sectional and Time-Series Dependence in Accounting Research. The Accounting Review 85 (2): 483-512.

Graham, J., C. Harvey, and S. Rajgopal. 2005. The Economic Implications of Corporate Financial reporting. Journal of Accounting and Economics 40 (1): 3-73.

Groysberg, B., P. Healy, N. Nohria, and G. Serafeim. 2012. What Makes Analysts Say "Buy"? Harvard Business Review 90 (11).

Gupta, A., F. Briscoe, and D. Hambrick. 2017. Evenhandedness in Resource Allocation: Its Relationship with CEO Ideology, Organizational Discretion, and Firm Performance. Academy of Management Journal 61 (5): 1848-1868.

Hambrick, D. 2007. Upper Echelons Theory: An Update. Academy of Management Review 32 (2): 334 343.

Hambrick, D. and P. Mason. 1984. Upper Echelons: The Organization as a Reflection of Its Top Managers. Academy of Management Review 9 (2): 193-206.

Healy, P. 2014. Wall Street Research. SSRN Scholarly Paper. Rochester, NY: Social Science Research Network.

Hong, H., J. Kubik, and A. Solomon. 2000. Security Analysts' Career Concerns and Herding of Earnings Forecasts. The Rand Journal of Economics: 121-144.

Huang, Q., F. Jiang, E. Lie, and K. Yang. 2014. The Role of Investment Banker Directors in M\&A. Journal of Financial Economics 112 (2): 269-286.

Ivković, Z., and N. Jegadeesh. 2004. The Timing and Value of Forecast and Recommendation Revisions. Journal of Financial Economics 73 (3): 433-463.

Kasznik, R., and B. Lev. 1995. To Warn or Not to Warn: Management Disclosures in the Face of an Earnings Surprise. The Accounting Review 70 (1): 113-134.

Lang, M. and R. Lundholm. 1996. Corporate Disclosure Policy and Analyst Behavior. The Accounting Review 71 (4): 467-492.

Law, K. and L. Mills. 2017. Military Experience and Corporate Tax Avoidance. Review of Accounting Studies 22 (1): 141-184.

Li, F. 2010. The Information Content of Forward-Looking Statements in Corporate Filings-A Naïve Bayesian Machine Learning Approach. Journal of Accounting Research 48 (5): 1049-1102.

Loh, R. and G. Mian. 2006. Do Accurate Earnings Forecasts Facilitate Superior Investment Recommendations? Journal of Financial Economics 80 (2): 455-483.

Loughran, T., and B. Mcdonald. 2011. When Is a Liability Not a Liability? Textual Analysis, Dictionaries, and 10-Ks. The Journal of Finance 66 (1): 35-65.

Malmendier, U., and G. Tate. 2009. Superstar CEOs. The Quarterly Journal of Economics 124 (4): $1593-$ 1638.

Masulis, R., C. Wang, and F. Xie. 2007. Corporate Governance and Acquirer Returns. The Journal of Finance 62 (4): 1851-1889.

Mayew, W. 2008. Evidence of Management Discrimination Among Analysts during Earnings Conference Calls. Journal of Accounting Research 46 (3): 627-659.

Mikhail, M., B. Walther, and R. Willis. 1997. Do Security Analysts Improve Their Performance with Experience? Journal of Accounting Research 35: 131-157. 1999. Does Forecast Accuracy Matter to Security Analysts? The Accounting Review 74 (2): 185200. 
Moeller, S., F. Schlingemann, and R. Stulz. 2005. Wealth Destruction on a Massive Scale? A Study of Acquiring-Firm Returns in the Recent Merger Wave. The Journal of Finance 60 (2): 757-782.

Neyland, J. 2016. Love or Money: The Effect of CEO Divorce on Firm Risk and Compensation. SSRN Scholarly Paper. Rochester, NY: Social Science Research Network.

Stickel, S. E. 1992. Reputation and Performance Among Security Analysts. The Journal of Finance 47 (5): 1811-1836.

Sunder, J., S. Sunder, and J. Zhang. 2017. Pilot CEOs and Corporate Innovation. Journal of Financial Economics 123 (1): 209-224.

Wang, I. 2007. Private Earnings Guidance and Its Implications for Disclosure Regulation. The Accounting Review 82 (5): 1299-1332.

Williams, P. 1996. The Relation between a Prior Earnings Forecast by Management and Analyst Response to a Current Management Forecast. The Accounting Review 71 (1): 103-115.

Williams, P., G. Moyes, and K. Park. 1996. Factors Affecting Earnings Forecast Revisions for the Buy-Side and Sell-Side Analyst. Accounting Horizons 10 (3): 112-121. 


\section{APPENDIX A}

\section{Steps to Identify Former Analyst CEO/CFOs in the IBES Database}

1. Match former analyst CEO/CFOs to the IBES recommendation file which contains analysts' last names and the first initial of their first names.

2. Hand-check the name-based matching to avoid errors caused by people with the same last name and first initial of the first name. The sources we rely on for hand-checking include at least one of the following: LinkedIn, BoardEx employment information, Bloomberg CEO/CFO profiles, Morningstar executive profiles, Brokercheck analyst profiles, Wall Street Journal executive profiles, Google searches, news articles, and press releases.

3. Based on (1) and (2), we obtain the IBES Estimator ID representing an analyst's brokerage identifier (which is a different ID in the recommendation versus the forecast databases) and an analyst's individual IBES Analyst ID (which is the same ID in both recommendation and forecast databases).

4. Merge the Estimator ID with the IBES analyst translation file to obtain brokerage names since IBES does not directly provide brokerage names. If an Estimator ID does not have a matched brokerage name in the translation file, we use one of the sources above-i.e., LinkedIn, etc.- to obtain the brokerage name.

5. Verify the employment history match between the CEO/CFO BoardEx records and IBES records. This step is necessary because different analysts may have the same last name, the same initial of first name, and the same brokerage employer. For example, Ross Taylor, CFO of Abaxis Inc., has sell-side analyst experience at Smith Barney from 1996 to 1999 (data source: BoardEx, LinkedIn and Bloomberg). However, there are two R. Taylor IBES analysts who worked at Smith Barney. The first was R. Taylor (IBES ID: 78814) from 2002 to 2017, and the second was R. Taylor (IBES ID: 43707) from 1997 to 1999. Without verification of employment history, we would not be able to correctly match the latter IBES analyst ID to Ross Taylor the CFO. 


\section{Appendix B \\ Variable Definitions}

\section{Dependent Variables:}

\section{1) Management Forecast Measures:}

Accuracy

Absolute value of management forecast error multiplied by (-1), where error is defined as management forecast of EPS (point or midpoint of the range forecast) minus actual EPS, divided by logged assets per share.

Relative Accuracy

Absolute difference between prior 60-day median analyst forecast and actual EPS minus the absolute difference between management forecast and actual EPS, divided by the absolute difference between prior 60-day median analyst forecast and actual EPS.

\section{2) Firm Performance Measures:}

$\mathrm{ROA}$

Three-Factor/Four-Factor CAR

Three-Factor/Four-Factor BHAR
Net income divided by total assets in the fiscal year.

Cumulative abnormal return (CAR) in the fiscal year, where abnormal return is computed using the Fama and French (1993) three-factor model or Carhart (1997) four-factor model.

Buy-and-hold abnormal return (BHAR) in the fiscal year, where abnormal return is computed using the Fama and French (1993) three-factor model or Carhart (1997) four-factor model.

\section{3) M\&A Performance Measures:}

Three-Factor/Four-Factor

CAR $(-2,+2)$

Three-Factor/Four-Factor $\operatorname{BHAR}(-2,+2)$
Cumulative abnormal returns (CAR) during the event window $(-2,+2)$ using Fama and French (1993) three-factor model or Carhart (1997) four-factor model.

Buy-and-hold abnormal returns (BHAR) during the event window $(-2,+2)$ using Fama and French (1993) three-factor model or Carhart (1997) four-factor model.

\section{Independent Variable of Interest in Main Tests:}

Former Analyst

Equals one if the firm's $\mathrm{CEO} / \mathrm{CFO}$ in the fiscal year has equity research analyst working experience and equals zero otherwise.

\section{Independent Variables of Interest in Cross-Sectional Tests:}

Better (Worse) Forecaster

Better (Worse) Recommender

\section{Control Variables:}

Equals one if the former analyst CEO/CFO had better (worse) forecast performance, where forecast performance is identified as better (worse) if the past relative forecast accuracy of this former analyst is higher than or equal to (less than) the median relative forecast accuracy of all IBES analysts in our sample and equals zero otherwise.

\section{1) Accuracy and Firm Performance Tests:}

Raw stock return

Return Volatility

$\mathrm{B} / \mathrm{M}$
Cumulative monthly raw stock return during the fiscal year.

Standard deviation of monthly raw stock returns during the fiscal year.

Ratio of book value to market value of common equity at the beginning of the fiscal year. 
Size

Earnings Volatility

HHI

$R \& D$

Horizon

Analyst Following

News

Reg FD

Beta

Loss

Litigate

Analyst Dispersion

Age

2) $M \& A$ Performance Tests:

\section{Acquirer Characteristics:}

Log (total assets)

Tobin's Q

ROA

Sales Growth

Leverage

Stock Price Run-Up
Natural logarithm of market value of equity at the beginning of the fiscal year.

Standard deviation of annual earnings over 5 years ending at fiscal year-end, divided by median asset value for the 5 years.

Hirschman-Herfindahl $(\mathrm{HH})$ index, calculated as the summation of squared market share (i.e., sale percentage) of each firm within industry in the fiscal year.

Equals one if research and development expense is greater than zero in the fiscal year and equals zero otherwise.

Management forecast horizon, measured as the number of days between the management earnings forecast announcement date and fiscal year end.

Natural logarithm of one plus the number of unique analysts who follow the firm in the fiscal year.

Equals one if the current fiscal-year EPS is greater than or equal to the last fiscal-year EPS and equals zero otherwise.

Equals one if the observation is related to the post-Reg FD period (after October 2000), and equals zero otherwise.

Equity beta using daily stock returns and value-weighted market index returns for the past 250 trading days ending at the fiscal year end, with a min. of 60 trading days.

Equals one if the firm reports a loss in the fiscal year, and equals zero otherwise.

Equals one for all firms in the biotechnology, computers, electronics and retail industries, and equals zero otherwise.

Standard deviation of analyst annual earnings forecasts divided by the median analyst forecast prior to the management earnings forecast announcement date.

Natural logarithm of number of years that have elapsed since the firm started in Compustat. 


\section{Target Characteristics:}

Public Target

Domestic Target

Deal Characteristics:

Relative Deal Size

Toehold

Competing Offer

Stock Deal

Cash Deal

Diversifying Acquisition

Tender Offer

Hostile

\section{Conference Call Variables:}

Managerial Answer Certainty

Analyst Forward-Looking Questions
Equals one for public target, and equals zero otherwise.

Equals one if the target is a domestic company, and equals zero otherwise.

Deal value divided by acquirer's market value of equity.

Equals one if the acquirer holds $5 \%$ or more of the target stock prior to the M\&A announcement date, and equals zero otherwise.

Equals one if a deal has competing bidders as identified by SDC, and equals zero otherwise.

Equals one for deals that are paid for $100 \%$ in stock, and equals zero otherwise.

Equals one for deals that are paid for $100 \%$ in cash, and equals zero otherwise.

Equals one if the target and the acquirer have different two-digit SIC codes, and equals zero otherwise.

Equals one for tender offers as identified by SDC, and equals zero otherwise.

Equals one if the acquisition was classified as hostile by SDC, and equals zero otherwise.

Percentage of words in a CEO or a CFO's answers to analyst questions during a conference call that make answers more 'uncertain' multiplied by $(-100)$, where uncertain words are from Loughran and McDonald (2011).

Proportion of sentences containing forward-looking statements during the analyst questions of a conference call, where forward-looking statements are from Li (2010). 
Table 1

Summary Statistics of Former Analyst CEO/CFOs for Main Tests

Panel A. Number of Former Analysts in Accuracy Tests

\begin{tabular}{|c|c|c|c|c|c|c|}
\hline \multirow[b]{3}{*}{ Total } & \multicolumn{3}{|c|}{ Accuracy } & \multicolumn{3}{|c|}{ Relative Accuracy } \\
\hline & \multicolumn{2}{|c|}{ Firm-years } & \multirow[t]{2}{*}{$\begin{array}{l}\text { Unique } \\
\text { analysts }\end{array}$} & \multicolumn{2}{|c|}{ Firm-years } & $\begin{array}{l}\text { Unique } \\
\text { analysts }\end{array}$ \\
\hline & 16,723 & $100.00 \%$ & & 13,191 & $100.00 \%$ & \\
\hline Non-Former Analysts & 16,520 & $98.79 \%$ & & 13,031 & $98.79 \%$ & \\
\hline Former Analysts & 203 & $1.21 \%$ & 64 & 160 & $1.21 \%$ & 54 \\
\hline
\end{tabular}

Panel B. Number of Former Analysts in M\&A Performance Tests

\begin{tabular}{|c|c|c|c|c|c|c|}
\hline & \multicolumn{6}{|c|}{ M\&A Performance } \\
\hline & \multicolumn{3}{|c|}{ 3-Factor CAR (BHAR) } & \multicolumn{3}{|c|}{ 4-Factor CAR (BHAR) } \\
\hline & \multicolumn{2}{|c|}{ Firm-years } & \multirow[t]{2}{*}{$\begin{array}{c}\text { Unique } \\
\text { Analysts }\end{array}$} & \multicolumn{2}{|c|}{ Firm-years } & $\begin{array}{l}\text { Unique } \\
\text { Analysts }\end{array}$ \\
\hline Total & 7,981 & $100.00 \%$ & & 7,981 & $100.00 \%$ & \\
\hline Non-Former Analysts & 7,865 & $98.55 \%$ & & 7,865 & $98.55 \%$ & \\
\hline Former Analysts & 116 & $1.45 \%$ & 33 & 116 & $1.45 \%$ & 33 \\
\hline
\end{tabular}

Panel C. Number of Former Analysts in Conference Call Tests

\begin{tabular}{|c|c|c|c|c|c|c|}
\hline \multirow[b]{4}{*}{ Total } & \multicolumn{6}{|c|}{ Managerial Answer Certainty } \\
\hline & \multicolumn{3}{|c|}{ Base Model } & \multicolumn{3}{|c|}{ Forward-Looking Questions } \\
\hline & \multicolumn{2}{|c|}{ Firm-quarters } & \multirow[t]{2}{*}{$\begin{array}{l}\text { Unique } \\
\text { Analysts }\end{array}$} & \multicolumn{2}{|c|}{ Firm-quarters } & $\begin{array}{l}\text { Unique } \\
\text { Analysts }\end{array}$ \\
\hline & 48,359 & $100.00 \%$ & & 48,359 & $100.00 \%$ & \\
\hline Non-Former Analysts & 47,507 & $98.24 \%$ & & 47,507 & $98.24 \%$ & \\
\hline Former Analysts & 852 & $1.76 \%$ & 60 & 852 & $1.76 \%$ & 60 \\
\hline
\end{tabular}


Panel D. Number of Former Analysts in Firm Performance Tests

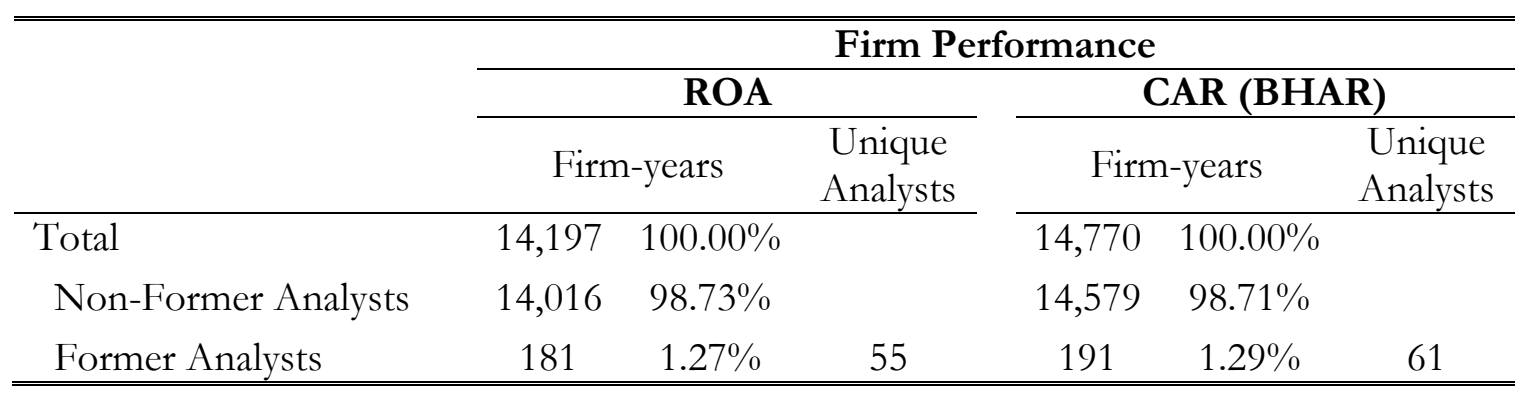


Table 2

Descriptive Statistics

Panel A. Accuracy Test Variables

\begin{tabular}{|c|c|c|c|c|c|c|c|c|}
\hline & $\mathrm{N}$ & Mean & S.D. & Min & P25 & Median & P75 & Max \\
\hline Relative Accuracy & 13,191 & -0.154 & 1.927 & -12.600 & -0.123 & 0.273 & 0.750 & 1.000 \\
\hline Accuracy & 16,723 & -0.089 & 0.243 & -1.862 & -0.056 & -0.019 & -0.007 & 0.000 \\
\hline Former Analyst & 16,723 & 0.012 & 0.110 & 0.000 & 0.000 & 0.000 & 0.000 & 1.000 \\
\hline Return & 16,723 & 0.138 & 0.489 & -0.794 & -0.157 & 0.097 & 0.344 & 2.138 \\
\hline Return Volatility & 16,723 & 0.112 & 0.067 & 0.029 & 0.066 & 0.096 & 0.139 & 0.382 \\
\hline $\mathrm{B} / \mathrm{M}$ & 16,723 & 0.489 & 0.346 & -0.097 & 0.252 & 0.419 & 0.637 & 1.933 \\
\hline Size & 16,723 & 7.147 & 1.714 & 3.102 & 6.000 & 7.077 & 8.259 & 11.645 \\
\hline Earnings Volatility & 16,723 & 0.059 & 0.083 & 0.002 & 0.016 & 0.031 & 0.066 & 0.538 \\
\hline HHI & 16,723 & 0.237 & 0.192 & 0.014 & 0.103 & 0.185 & 0.309 & 0.996 \\
\hline $\mathrm{R} \& \mathrm{D}$ & 16,723 & 0.441 & 0.496 & 0.000 & 0.000 & 0.000 & 1.000 & 1.000 \\
\hline Horizon & 16,723 & 114.461 & 100.941 & 9.000 & 58.000 & 68.000 & 154.000 & 485.000 \\
\hline Analyst Following & 16,723 & 9.155 & 6.919 & 0.000 & 4.000 & 7.000 & 13.000 & 31.000 \\
\hline Log (Analyst Following+1) & 16,723 & 2.063 & 0.760 & 0.000 & 1.609 & 2.079 & 2.639 & 3.466 \\
\hline News & 16,723 & 0.615 & 0.487 & 0.000 & 0.000 & 1.000 & 1.000 & 1.000 \\
\hline FD & 16,723 & 0.905 & 0.294 & 0.000 & 1.000 & 1.000 & 1.000 & 1.000 \\
\hline Beta & 16,723 & 1.010 & 0.485 & 0.025 & 0.680 & 0.974 & 1.292 & 2.502 \\
\hline Loss & 16,723 & 0.155 & 0.361 & 0.000 & 0.000 & 0.000 & 0.000 & 1.000 \\
\hline Litigate & 16,723 & 0.316 & 0.465 & 0.000 & 0.000 & 0.000 & 1.000 & 1.000 \\
\hline Analyst Dispersion & 16,723 & 0.022 & 0.071 & -0.283 & 0.004 & 0.011 & 0.025 & 0.440 \\
\hline
\end{tabular}


Panel B. M\&A Test Variables

\begin{tabular}{|c|c|c|c|c|c|c|c|c|}
\hline & $\mathrm{N}$ & Mean & S.D. & Min & P25 & Median & P75 & Max \\
\hline Three-Factor CAR $(-2,+2)$ & 7,981 & 0.007 & 0.067 & -0.210 & -0.023 & 0.004 & 0.035 & 0.304 \\
\hline Three-Factor BHAR $(-2,+2)$ & 7,981 & 0.007 & 0.068 & -0.207 & -0.024 & 0.003 & 0.034 & 0.312 \\
\hline Four-Factor CAR $(-2,+2)$ & 7,981 & 0.007 & 0.068 & -0.212 & -0.023 & 0.004 & 0.035 & 0.305 \\
\hline Four-Factor BHAR $(-2,+2)$ & 7,981 & 0.007 & 0.069 & -0.210 & -0.024 & 0.003 & 0.035 & 0.312 \\
\hline $\mathrm{B} / \mathrm{M}$ & 7,981 & 0.483 & 0.337 & 0.048 & 0.261 & 0.405 & 0.605 & 2.480 \\
\hline Log (total assets) & 7,981 & 7.775 & 1.818 & 2.383 & 6.493 & 7.659 & 8.986 & 13.305 \\
\hline Tobin's Q & 7,981 & 2.032 & 1.278 & 0.659 & 1.234 & 1.639 & 2.314 & 8.870 \\
\hline ROA & 7,981 & 0.042 & 0.092 & -0.941 & 0.018 & 0.047 & 0.079 & 0.237 \\
\hline Sales Growth & 7,981 & 0.262 & 0.587 & -0.865 & 0.044 & 0.134 & 0.285 & 6.907 \\
\hline Leverage & 7,981 & 0.247 & 0.182 & 0.000 & 0.100 & 0.234 & 0.369 & 0.847 \\
\hline Stock Price Run-Up & 7,981 & 0.127 & 0.541 & -1.042 & -0.113 & 0.053 & 0.256 & 13.616 \\
\hline Public Target & 7,981 & 0.189 & 0.392 & 0.000 & 0.000 & 0.000 & 0.000 & 1.000 \\
\hline Domestic Target & 7,981 & 0.856 & 0.351 & 0.000 & 1.000 & 1.000 & 1.000 & 1.000 \\
\hline Relative Deal Size & 7,981 & 0.115 & 0.232 & 0.000 & 0.011 & 0.037 & 0.109 & 2.086 \\
\hline Toehold & 7,981 & 0.041 & 0.199 & 0.000 & 0.000 & 0.000 & 0.000 & 1.000 \\
\hline Competing Offer & 7,981 & 0.010 & 0.100 & 0.000 & 0.000 & 0.000 & 0.000 & 1.000 \\
\hline Stock Deal & 7,981 & 0.069 & 0.254 & 0.000 & 0.000 & 0.000 & 0.000 & 1.000 \\
\hline Cash Deal & 7,981 & 0.418 & 0.493 & 0.000 & 0.000 & 0.000 & 1.000 & 1.000 \\
\hline Diversifying Acquisition & 7,981 & 0.404 & 0.491 & 0.000 & 0.000 & 0.000 & 1.000 & 1.000 \\
\hline Tender Offer & 7,981 & 0.052 & 0.222 & 0.000 & 0.000 & 0.000 & 0.000 & 1.000 \\
\hline Hostile & 7,981 & 0.001 & 0.035 & 0.000 & 0.000 & 0.000 & 0.000 & 1.000 \\
\hline
\end{tabular}


Panel C: Conference Call Test Variables

\begin{tabular}{|c|c|c|c|c|c|c|c|c|}
\hline & $\mathrm{N}$ & Mean & S.D. & Min & P25 & Median & P75 & Max \\
\hline Managerial Answer Certainty & 48,359 & -0.346 & 0.154 & -0.791 & -0.439 & -0.328 & -0.235 & -0.052 \\
\hline Forward-Looking Questions & 48,359 & 0.237 & 0.069 & 0.000 & 0.192 & 0.231 & 0.275 & 1.000 \\
\hline $\begin{array}{l}\text { Quintile Rank Forward- } \\
\text { Looking Questions }\end{array}$ & 48,359 & 1.987 & 1.416 & 0.000 & 1.000 & 2.000 & 3.000 & 4.000 \\
\hline $\begin{array}{l}\text { Top Quintile Forward-Looking } \\
\text { Questions }\end{array}$ & 48,359 & 0.198 & 0.399 & 0.000 & 0.000 & 0.000 & 0.000 & 1.000 \\
\hline $\mathrm{B} / \mathrm{M}$ & 48,359 & 0.456 & 0.325 & -0.473 & 0.244 & 0.399 & 0.606 & 2.773 \\
\hline Size & 48,359 & 7.667 & 1.538 & 2.860 & 6.600 & 7.594 & 8.671 & 11.598 \\
\hline Raw Stock Return & 48,359 & 0.154 & 0.427 & -0.823 & -0.090 & 0.128 & 0.338 & 2.391 \\
\hline Return Volatility & 48,359 & 0.094 & 0.051 & 0.029 & 0.058 & 0.082 & 0.116 & 0.398 \\
\hline Earnings Volatility & 48,359 & 0.049 & 0.071 & 0.002 & 0.014 & 0.028 & 0.055 & 0.726 \\
\hline Analyst Dispersion & 48,359 & 0.036 & 0.046 & -0.024 & 0.012 & 0.022 & 0.043 & 0.209 \\
\hline
\end{tabular}


Panel D. Firm Performance Test Variables

\begin{tabular}{|c|c|c|c|c|c|c|c|c|}
\hline & $\mathrm{N}$ & Mean & S.D. & Min & P25 & Median & P75 & Max \\
\hline $\mathrm{ROA}$ & 14,197 & 0.023 & 0.231 & -9.130 & 0.014 & 0.045 & 0.082 & 0.410 \\
\hline Three-Factor CAR (one year) & 14,770 & -0.046 & 0.638 & -2.506 & -0.357 & -0.035 & 0.271 & 2.821 \\
\hline Three-Factor BHAR (one year) & 14,770 & -0.257 & 1.193 & -11.919 & -0.479 & -0.085 & 0.230 & 2.661 \\
\hline Four-Factor CAR (one year) & 14,770 & -0.046 & 0.643 & -2.541 & -0.359 & -0.032 & 0.277 & 2.807 \\
\hline Four-Factor BHAR (one year) & 14,770 & -0.262 & 1.200 & -12.093 & -0.485 & -0.084 & 0.232 & 2.654 \\
\hline Return Volatility & 14,197 & 0.109 & 0.067 & 0.016 & 0.064 & 0.093 & 0.135 & 0.536 \\
\hline $\mathrm{B} / \mathrm{M}$ & 14,197 & 0.461 & 0.370 & -6.173 & 0.243 & 0.398 & 0.608 & 4.933 \\
\hline Size & 14,197 & 7.392 & 1.559 & 1.033 & 6.291 & 7.296 & 8.442 & 10.745 \\
\hline Earnings Volatility & 14,197 & 0.063 & 0.191 & 0.000 & 0.015 & 0.030 & 0.062 & 7.796 \\
\hline HHI & 14,197 & 0.238 & 0.191 & 0.014 & 0.104 & 0.186 & 0.309 & 0.987 \\
\hline $\mathrm{R} \& \mathrm{D}$ & 14,197 & 0.443 & 0.497 & 0.000 & 0.000 & 0.000 & 1.000 & 1.000 \\
\hline Analyst Following & 14,197 & 10.112 & 6.772 & 2.000 & 5.000 & 8.000 & 14.000 & 31.000 \\
\hline Log (Analyst Following+1) & 14,197 & 2.224 & 0.618 & 1.099 & 1.792 & 2.197 & 2.708 & 3.466 \\
\hline Litigate & 14,197 & 0.320 & 0.466 & 0.000 & 0.000 & 0.000 & 1.000 & 1.000 \\
\hline Analyst Dispersion & 14,197 & 0.041 & 0.098 & -0.355 & 0.012 & 0.023 & 0.045 & 0.614 \\
\hline Age & 14,197 & 2.952 & 0.733 & 0.693 & 2.398 & 2.890 & 3.664 & 4.025 \\
\hline
\end{tabular}


Table 3

Former Analyst CEO/CFO and Earnings Guidance Accuracy

This table compares the earnings guidance accuracy of former analyst executives to that of other executives. Accuracy is the absolute value of the forecast error multiplied by negative one and divided by logged assets per share. Relative accuracy benchmarks management's forecast error to that of the trailing analyst consensus for the same firm-year. Former analyst equals one if the firm's CEO/CFO in that fiscal period has equity research analyst working experience and zero otherwise. $t$-statistics in parentheses are based on standard errors which are two-way clustered at firm and year level. Detailed definitions of remaining variables are in Appendix B.

\begin{tabular}{|c|c|c|}
\hline & \multicolumn{2}{|c|}{ Dependent Variables: Management Earnings Forecast Accuracy } \\
\hline & Accuracy & Relative Accuracy \\
\hline \multirow[t]{2}{*}{ Former Analyst } & $0.0242 * *$ & $0.2180 * *$ \\
\hline & $(1.97)$ & $(2.07)$ \\
\hline \multirow[t]{2}{*}{ Return } & $0.0372 * * *$ & 0.0119 \\
\hline & $(5.22)$ & $(0.30)$ \\
\hline \multirow[t]{2}{*}{ Return Volatility } & $-0.5157 * * *$ & 0.7005 \\
\hline & $(-8.82)$ & $(1.50)$ \\
\hline \multirow[t]{2}{*}{$\mathrm{B} / \mathrm{M}$} & -0.0083 & $-0.1739 * *$ \\
\hline & $(-0.69)$ & $(-2.59)$ \\
\hline \multirow[t]{2}{*}{ Size } & $-0.0154 * * *$ & $-0.0433 * * *$ \\
\hline & $(-6.79)$ & $(-3.05)$ \\
\hline \multirow[t]{2}{*}{ Earnings Volatility } & $-0.4505 * * *$ & -0.3265 \\
\hline & $(-5.99)$ & $(-1.38)$ \\
\hline \multirow[t]{2}{*}{ HHI } & 0.0143 & 0.1107 \\
\hline & $(1.09)$ & $(0.96)$ \\
\hline \multirow[t]{2}{*}{$\mathrm{R} \& \mathrm{D}$} & 0.0022 & 0.0120 \\
\hline & $(0.39)$ & $(0.16)$ \\
\hline \multirow[t]{2}{*}{ Horizon } & $-0.0006^{* * *}$ & $-0.0006^{* * *}$ \\
\hline & $(-14.79)$ & $(-3.32)$ \\
\hline \multirow[t]{2}{*}{ Analyst Following } & $0.0474^{* * *}$ & $0.0703^{* * *}$ \\
\hline & (8.21) & (3.04) \\
\hline \multirow[t]{2}{*}{ News } & $0.0266^{* * *}$ & -0.0179 \\
\hline & $(5.43)$ & $(-0.36)$ \\
\hline \multirow[t]{2}{*}{ Reg FD } & -0.0006 & $0.3248^{* * *}$ \\
\hline & $(-0.20)$ & $(11.76)$ \\
\hline \multirow[t]{2}{*}{ Beta } & 0.0076 & -0.0840 \\
\hline & $(0.83)$ & $(-1.49)$ \\
\hline \multirow[t]{2}{*}{ Loss } & $-0.1169 * * *$ & -0.1229 \\
\hline & $(-10.94)$ & $(-1.61)$ \\
\hline
\end{tabular}




\begin{tabular}{lcc} 
Litigate & -0.0019 & -0.1283 \\
& $(-0.19)$ & $(-1.63)$ \\
Analyst Dispersion & $0.1919^{* * *}$ & $-0.5080^{* *}$ \\
& $(3.74)$ & $(-2.56)$ \\
Year Fixed Effect & Yes & Yes \\
Industry Fixed Effect & Yes & Yes \\
Clustered Std. Err. & Firm \& Year & Firm \& Year \\
\# of Observations & 16,723 & 13,191 \\
Adj. R-Squared & 0.253 & 0.008 \\
\hline \hline
\end{tabular}




\section{Table 4 \\ Former Analyst CEO/CFO and M\&A Performance}

This table compares the M\&A performance of former analyst executives to that of other executives. Three-Factor CAR (BHAR) represents the five-day cumulative (buy-and-hold) abnormal returns centered on the acquisition announcement date using the Fama and French (1993) three-factor model. Four-Factor CAR (BHAR) represents the five-day cumulative (buyand-hold) abnormal returns centered on the acquisition announcement date using the Carhart (1997) four-factor model. Former analyst equals one if the firm's CEO/CFO in that fiscal period has equity research analyst working experience and zero otherwise. $t$-statistics in parentheses are based on standard errors which are two-way clustered at firm and year level. Detailed definitions of remaining variables are in Appendix B.

\begin{tabular}{|c|c|c|c|c|}
\hline & \multicolumn{4}{|c|}{ Dependent Variables: Measures of M\&A Performance } \\
\hline & $\begin{array}{c}\text { Three-Factor } \\
\text { CAR }\end{array}$ & $\begin{array}{c}\text { Three-Factor } \\
\text { BHAR }\end{array}$ & $\begin{array}{c}\text { Four-Factor } \\
\text { CAR }\end{array}$ & $\begin{array}{c}\text { Four-Factor } \\
\text { BHAR }\end{array}$ \\
\hline \multirow[t]{2}{*}{ Former Analyst } & $0.0112 * *$ & $0.0107 * *$ & $0.0118 * * *$ & $0.0112 * *$ \\
\hline & $(2.54)$ & $(2.40)$ & $(2.68)$ & $(2.55)$ \\
\hline \multirow{2}{*}{$\mathrm{B} / \mathrm{M}$} & -0.0031 & -0.0037 & -0.0026 & -0.0030 \\
\hline & $(-0.75)$ & $(-0.88)$ & $(-0.62)$ & $(-0.72)$ \\
\hline \multirow[t]{2}{*}{ Log (total assets) } & $-0.0026 * * *$ & $-0.0025^{* * *}$ & $-0.0027 * * *$ & $-0.0027 * * *$ \\
\hline & $(-3.27)$ & $(-3.16)$ & $(-3.33)$ & $(-3.23)$ \\
\hline \multirow[t]{2}{*}{ Tobin's Q } & -0.0004 & -0.0005 & -0.0008 & -0.0008 \\
\hline & $(-0.54)$ & $(-0.61)$ & $(-1.04)$ & $(-1.02)$ \\
\hline \multirow[t]{2}{*}{ ROA } & 0.0128 & 0.0128 & 0.0156 & 0.0157 \\
\hline & $(0.95)$ & $(0.98)$ & $(1.24)$ & $(1.27)$ \\
\hline \multirow[t]{2}{*}{ Sales Growth } & 0.0020 & 0.0021 & 0.0018 & 0.0020 \\
\hline & $(1.27)$ & $(1.38)$ & $(1.18)$ & $(1.30)$ \\
\hline \multirow[t]{2}{*}{ Leverage } & $0.0162^{* * *}$ & $0.0159 * * *$ & $0.0164 * * *$ & $0.0162^{* * *}$ \\
\hline & $(2.66)$ & $(2.63)$ & $(2.63)$ & $(2.60)$ \\
\hline \multirow[t]{2}{*}{ Price Run-Up } & $-0.0080 * *$ & $-0.0080 * *$ & $-0.0070 * *$ & $-0.0072 * *$ \\
\hline & $(-2.39)$ & $(-2.29)$ & $(-2.05)$ & $(-2.06)$ \\
\hline \multirow[t]{2}{*}{ Public Target } & $-0.0092 * * *$ & $-0.0092^{* * *}$ & $-0.0093 * * *$ & $-0.0093 * * *$ \\
\hline & $(-4.07)$ & $(-4.00)$ & $(-4.23)$ & $(-4.13)$ \\
\hline \multirow[t]{2}{*}{ Domestic Target } & -0.0005 & -0.0005 & -0.0012 & -0.0012 \\
\hline & $(-0.18)$ & $(-0.18)$ & $(-0.46)$ & $(-0.47)$ \\
\hline \multirow[t]{2}{*}{ Relative Deal Size } & $0.0109 *$ & $0.0109 *$ & $0.0124 * *$ & $0.0123 * *$ \\
\hline & $(1.95)$ & $(1.89)$ & $(2.25)$ & (2.19) \\
\hline \multirow[t]{2}{*}{ Toehold } & $-0.0060 *$ & $-0.0062^{*}$ & $-0.0063^{*}$ & $-0.0065^{*}$ \\
\hline & $(-1.81)$ & $(-1.79)$ & $(-1.82)$ & $(-1.82)$ \\
\hline
\end{tabular}




\begin{tabular}{lcccc} 
Competing Offer & $-0.0167^{* *}$ & $-0.0172^{* *}$ & $-0.0179^{* *}$ & $-0.0182^{* *}$ \\
& $(-2.12)$ & $(-2.16)$ & $(-2.20)$ & $(-2.23)$ \\
Stock Deal & -0.0077 & -0.0082 & -0.0064 & -0.0069 \\
& $(-1.46)$ & $(-1.55)$ & $(-1.20)$ & $(-1.29)$ \\
Cash Deal & $0.0038^{*}$ & $0.0037^{*}$ & $0.0041^{* *}$ & $0.0040^{* *}$ \\
& $(1.88)$ & $(1.81)$ & $(2.04)$ & $(1.97)$ \\
Diversifying & $-0.0050^{* * *}$ & $-0.0049^{* * *}$ & $-0.0045^{* * *}$ & $-0.0045^{* * *}$ \\
Acquisition & $(-3.77)$ & $(-3.59)$ & $(-3.32)$ & $(-3.17)$ \\
& $0.0091^{* *}$ & $0.0092^{* *}$ & $0.0093^{* *}$ & $0.0093^{* *}$ \\
Tender Offer & $(2.13)$ & $(2.11)$ & $(2.19)$ & $(2.16)$ \\
& -0.0233 & -0.0215 & -0.0214 & -0.0196 \\
Hostile & $(-1.19)$ & $(-1.14)$ & $(-1.06)$ & $(-1.00)$ \\
& Yes & Yes & Yes & Yes \\
Year FE & Yes & Yes & Yes & Yes \\
Industry FE & Firm \& Year & Firm \& Year & Firm \& Year & Firm \& Year \\
Clustered Std. Err. & 7,981 & 7,981 & 7,981 & 7,981 \\
\# Observations & 0.020 & 0.019 & 0.018 & 0.018 \\
Adj. R-Squared & & & & \\
\hline \hline
\end{tabular}


Table 5

Former Analyst CEO/CFO Earnings Guidance Accuracy and M\&A Performance:

\section{Cross-Sectional Evidence on Past Performance}

This table compares the earnings guidance accuracy and M\&A performance of former analyst executives to that of other executives. The novel feature is that it uses the IBES database to compile performance records for former analyst executives. Better (Worse) Forecaster is equal to one if the $\mathrm{CEO} / \mathrm{CFO}$ in that fiscal period is a former analyst and had better forecasting performance, where better connotes past relative forecast accuracy higher (lower) than the median of IBES analysts in our sample and zero otherwise. Better (Worse) Recommender is equal to one if the $\mathrm{CEO} / \mathrm{CFO}$ in that fiscal period is a former analyst and had better recommendation performance, where better connotes past relative recommendation profitability higher (lower) than the median of IBES analysts in our sample and zero otherwise. Relative accuracy benchmarks management's forecast error to that of the trailing analyst consensus for the same firm-year. Three-Factor CAR (BHAR) represents the fiveday cumulative (buy-and-hold) abnormal returns centered on the acquisition announcement date using the Fama and French (1993) threefactor model. Four-Factor CAR (BHAR) represents the five-day cumulative (buy-and-hold) abnormal returns centered on the acquisition announcement date using the Carhart (1997) four-factor model. $t$-statistics in parentheses are based on standard errors which are two-way clustered at firm and year level. Detailed definitions of remaining variables are in Appendix B.

\begin{tabular}{|c|c|c|c|c|c|}
\hline & \multicolumn{5}{|c|}{ Dependent Variables } \\
\hline & \multirow[b]{2}{*}{ Relative Accuracy } & \multicolumn{4}{|c|}{ Measures of M\&A Performance } \\
\hline & & $\begin{array}{l}\text { Three-Factor } \\
\text { CAR }(-2,+2)\end{array}$ & $\begin{array}{c}\text { Three-Factor } \\
\operatorname{BHAR}(-2,+2)\end{array}$ & $\begin{array}{l}\text { Four-Factor } \\
\text { CAR }(-2,+2)\end{array}$ & $\begin{array}{c}\text { Four-Factor } \\
\operatorname{BHAR}(-2,+2)\end{array}$ \\
\hline \multirow[t]{2}{*}{ Better Forecaster } & $0.5146 * *$ & & & & \\
\hline & $(2.43)$ & & & & \\
\hline Worse Forecaster & $\begin{array}{c}0.3229 \\
(1.61)\end{array}$ & & & & \\
\hline \multirow[t]{2}{*}{ Better Recommender } & & $0.0077 * *$ & $0.0072 * *$ & $0.0116 * * *$ & $0.0110 * * *$ \\
\hline & & $(2.49)$ & $(2.36)$ & $(6.28)$ & $(8.24)$ \\
\hline
\end{tabular}


Worse Recommender

0.0062

0.0057

0.0031

0.0025

Control Variables

(0.46)

(0.43)

Included

Included

(0.23)

(0.19)

Year Fixed Effect

Yes

Yes

Yes

Included

Included

Yes

Yes

Yes

Yes

Clustered Std. Err. Firm \& Year

\# of Observations

13,692

Firm \& Year

8,328

Firm \& Year

8,328

Firm \& Year

8,328

0.018

Yes

Yes

Firm \& Year

8,328

0.018 
Table 6

\section{Former Analyst CEO/CFO and Conference Call Interaction}

This table compares former analyst executives' conference call answers to those of other executives. Managerial Answer Certainty is the percentage of words in CEO/CFO answers to analyst questions during a conference call that convey uncertainty multiplied by -100 , where uncertain words are from Loughran and McDonald (2011). Forward-Looking Questions is the proportion of analyst questions containing forward-looking terms during the conference call, where forward-looking terms are from $\mathrm{Li}$ (2010). Quintile Rank is a rank variable coded zero through four, with four representing the top forward-looking quintile. Top quintile is an indicator variable coded as one for the top forward-looking quintile and zero otherwise. Former analyst equals one if the firm's CEO/CFO in that fiscal period has equity research analyst working experience and zero otherwise. $t$-statistics in parentheses are based on standard errors which are two-way clustered at firm and year level. Detailed definitions of remaining variables are in Appendix B.

\begin{tabular}{|c|c|c|c|}
\hline \multicolumn{4}{|c|}{ Dependent Variables: Managerial Answer Certainty } \\
\hline & & $\begin{array}{c}\text { Quintile Rank } \\
\text { Forward-Looking } \\
\text { Questions }\end{array}$ & $\begin{array}{c}\text { Top Quintile } \\
\text { Forward-Looking } \\
\text { Questions }\end{array}$ \\
\hline Former Analyst & $0.0461 * *$ & 0.0251 & $0.0408 * *$ \\
\hline Forward-Looking Questions & $(2.36)$ & $\begin{array}{c}(1.11) \\
-0.0001 \\
(-0.17)\end{array}$ & $\begin{array}{c}(2.12) \\
0.0104 * * \\
(2.39)\end{array}$ \\
\hline $\begin{array}{l}\text { Former Analyst } \cdot \text { Forward-Looking } \\
\text { Questions }\end{array}$ & & $0.0103 * *$ & $0.0260 *$ \\
\hline & & $(2.20)$ & $(1.80)$ \\
\hline $\mathrm{B} / \mathrm{M}$ & $\begin{array}{c}0.0113 \\
(1.43)\end{array}$ & $\begin{array}{c}0.0114 \\
(1.44)\end{array}$ & $\begin{array}{c}0.0111 \\
(1.40)\end{array}$ \\
\hline Size & $\begin{array}{c}-0.0051 * * \\
(-2.28)\end{array}$ & $\begin{array}{c}-0.0051 * * \\
(-2.30)\end{array}$ & $\begin{array}{c}-0.0053^{* *} \\
(-2.39)\end{array}$ \\
\hline Raw Stock Return & $\begin{array}{c}0.0014 \\
(0.40)\end{array}$ & $\begin{array}{c}0.0014 \\
(0.41)\end{array}$ & $\begin{array}{c}0.0015 \\
(0.45)\end{array}$ \\
\hline Return Volatility & $\begin{array}{c}-0.0098 \\
(-0.22)\end{array}$ & $\begin{array}{c}-0.0095 \\
(-0.22)\end{array}$ & $\begin{array}{c}-0.0126 \\
(-0.29)\end{array}$ \\
\hline Earnings Volatility & $\begin{array}{c}0.0521 \\
(1.64)\end{array}$ & $\begin{array}{c}0.0519 \\
(1.63)\end{array}$ & $\begin{array}{c}0.0516 \\
(1.63)\end{array}$ \\
\hline Analyst Dispersion & $\begin{array}{c}0.0749 * * * \\
(2.92)\end{array}$ & $\begin{array}{c}0.0749 * * * \\
(2.93)\end{array}$ & $\begin{array}{c}0.0733^{* * *} \\
(2.89)\end{array}$ \\
\hline Year Fixed Effect & Yes & Yes & Yes \\
\hline Industry Fixed Effect & Yes & Yes & Yes \\
\hline Clustered Std. Err. & Firm \& Year & Firm \& Year & Firm \& Year \\
\hline \# of Observations & 48,359 & 48,359 & 48,359 \\
\hline Adj. R-Squared & 0.069 & 0.069 & 0.070 \\
\hline
\end{tabular}


Table 7

\section{Former Analyst CEO/CFO and Overall Firm Performance}

This table compares overall firm performance of former analyst executives to that of other executives. $R O A$ is net income divided by total assets. Three-Factor CAR (BHAR) represents the cumulative (buy-and-hold) abnormal returns computed based on the Fama and French (1993) three-factor model during a given fiscal year. Four-Factor CAR (BHAR) represents the cumulative (buy-and-hold) abnormal returns computed based on the Carhart (1997) four-factor model during a given fiscal year. Former analyst equals one if the firm's CEO/CFO in that fiscal period has equity research analyst working experience and zero otherwise. $t$-statistics in parentheses are based on standard errors which are two-way clustered at firm and year level. Detailed definitions of remaining variables are in Appendix B.

\begin{tabular}{|c|c|c|c|c|c|}
\hline & \multicolumn{5}{|c|}{ Dependent Variables: Measures of Firm Performance } \\
\hline & ROA & $\begin{array}{c}\text { Three-Factor } \\
\text { CAR }\end{array}$ & $\begin{array}{c}\text { Three-Factor } \\
\text { BHAR }\end{array}$ & $\begin{array}{c}\text { Four-Factor } \\
\text { CAR }\end{array}$ & $\begin{array}{c}\text { Four-Factor } \\
\text { BHAR }\end{array}$ \\
\hline Former Analyst & $0.0394 * * *$ & $0.0911 * * *$ & $0.0778 * *$ & $0.0955^{* * *}$ & $0.0798 * *$ \\
\hline & $(2.63)$ & $(3.18)$ & $(2.40)$ & $(4.19)$ & $(1.97)$ \\
\hline Return Volatility & $\begin{array}{c}-0.4491 * * * \\
(-5.37)\end{array}$ & $\begin{array}{c}-0.2135 \\
(-0.42)\end{array}$ & $\begin{array}{c}-2.4647 * * * \\
(-3.44)\end{array}$ & $\begin{array}{c}-0.3093 \\
(-0.71)\end{array}$ & $\begin{array}{c}-2.4512^{* * *} \\
(-3.73)\end{array}$ \\
\hline $\mathrm{B} / \mathrm{M}$ & $\begin{array}{c}-0.0597 * * * \\
(-6.56)\end{array}$ & $\begin{array}{c}0.4385^{* * *} \\
(6.54)\end{array}$ & $\begin{array}{c}0.6562^{* * *} \\
(6.54)\end{array}$ & $\begin{array}{c}0.4373^{* * *} \\
\quad(6.82)\end{array}$ & $\begin{array}{c}0.6643^{* * *} \\
(6.99)\end{array}$ \\
\hline Size & $\begin{array}{c}0.0035 \\
(0.58)\end{array}$ & $\begin{array}{c}-0.0866^{* * *} \\
(-8.93)\end{array}$ & $\begin{array}{c}-0.0935^{* * *} \\
(-6.33)\end{array}$ & $\begin{array}{c}-0.0919 * * * \\
(-10.14)\end{array}$ & $\begin{array}{c}-0.0977 * * * \\
(-6.60)\end{array}$ \\
\hline Earnings Volatility & $\begin{array}{c}-0.1722^{* * *} \\
(-3.74)\end{array}$ & $\begin{array}{c}-0.1046^{* *} \\
(-2.33)\end{array}$ & $\begin{array}{c}-0.3624^{*} \\
(-1.77)\end{array}$ & $\begin{array}{c}-0.1146^{* * *} \\
(-2.69)\end{array}$ & $\begin{array}{c}-0.3340 \\
(-1.57)\end{array}$ \\
\hline HHI & $\begin{array}{c}-0.0019 \\
(-0.14)\end{array}$ & $\begin{array}{c}0.0664 \\
(1.59)\end{array}$ & $\begin{array}{c}0.1056 \\
(1.56)\end{array}$ & $\begin{array}{c}0.0625 \\
(1.53)\end{array}$ & $\begin{array}{c}0.1059 \\
(1.52)\end{array}$ \\
\hline
\end{tabular}




\begin{tabular}{|c|c|c|c|c|c|}
\hline $\mathrm{R} \& \mathrm{D}$ & $\begin{array}{c}-0.0139 * * \\
(-2.14)\end{array}$ & $\begin{array}{c}0.0582^{* * *} \\
(3.18)\end{array}$ & $\begin{array}{c}0.0422 \\
(1.13)\end{array}$ & $\begin{array}{c}0.0647 * * * \\
(3.73)\end{array}$ & $\begin{array}{c}0.0530 \\
(1.56)\end{array}$ \\
\hline \multirow[t]{2}{*}{ Analyst Following } & -0.0007 & $0.2011 * * *$ & $0.2988^{* * *}$ & $0.2036 * * *$ & $0.3056^{* * *}$ \\
\hline & $(-0.07)$ & $(10.06)$ & $(8.86)$ & $(10.73)$ & $(9.56)$ \\
\hline \multirow[t]{2}{*}{ Litigate } & -0.0077 & -0.0608 & -0.1000 & -0.0534 & -0.0891 \\
\hline & $(-1.10)$ & $(-1.44)$ & $(-1.51)$ & $(-1.22)$ & $(-1.24)$ \\
\hline \multirow[t]{2}{*}{ Analyst Dispersion } & $0.0501 *$ & 0.0496 & 0.1130 & 0.0891 & 0.1387 \\
\hline & $(1.91)$ & $(0.60)$ & $(1.15)$ & $(1.11)$ & $(1.47)$ \\
\hline \multirow[t]{2}{*}{ Age } & $0.0141 * * *$ & $0.0698^{* * *}$ & $0.1221 * * *$ & $0.0765^{* * *}$ & $0.1316^{* * *}$ \\
\hline & $(3.47)$ & (4.14) & $(3.42)$ & $(4.66)$ & (3.91) \\
\hline Year Fixed Effect & Yes & Yes & Yes & Yes & Yes \\
\hline Industry Fixed Effect & Yes & Yes & Yes & Yes & Yes \\
\hline Clustered Std. Err. & Firm \& Year & Firm \& Year & Firm \& Year & Firm \& Year & Firm \& Year \\
\hline \# of Observations & 14,197 & 14,770 & 14,770 & 14,770 & 14,770 \\
\hline Adj. R-Squared & 0.076 & 0.092 & 0.096 & 0.091 & 0.093 \\
\hline
\end{tabular}




\section{Table 8 \\ CEO/CFO Placebo Tests: \\ Pseudo-Former Analysts and Alternative Previous Work Experience}

This table re-examines the main CEO/CFO results with pseudo-former analysts and alternative work experience variables. Pseudo-Former analyst equals one for firm-years prior to the start date or after the end date of the former analyst CEO/CFO's tenure and equals zero otherwise. General Financial Analyst equals one for work experience as a financial analyst, excluding sell-side and buy-side analysts. Accounting/Finance Experience equals one for work experience in accounting or finance, excluding sellside and buy-side analysts. Engineering Experience equals one for work experience in engineering. $t$ statistics in parentheses are based on standard errors which are two-way clustered at firm and year level. Detailed definitions of remaining variables are in Appendix B.

\begin{tabular}{|c|c|c|c|c|}
\hline \multirow[b]{3}{*}{ Dependent Variables } & \multicolumn{4}{|c|}{ Coefficients on Previous Working Experience } \\
\hline & $(1)$ & $(2)$ & (3) & (4) \\
\hline & $\begin{array}{l}\text { Pseudo- } \\
\text { Former } \\
\text { Analysts }\end{array}$ & $\begin{array}{c}\text { General } \\
\text { Financial } \\
\text { Analysts }\end{array}$ & $\begin{array}{l}\text { Accounting/ } \\
\text { Finance }\end{array}$ & Engineering \\
\hline \multicolumn{5}{|l|}{ Guidance Accuracy: } \\
\hline \multirow[t]{2}{*}{ Relative Accuracy } & 0.0857 & -0.2154 & 0.0041 & -0.0859 \\
\hline & $(1.47)$ & $(-0.99)$ & $(0.12)$ & $(-1.11)$ \\
\hline \# of Observations & 13234 & 16,176 & 16,176 & 16,176 \\
\hline \multicolumn{5}{|l|}{ M\&A Performance: } \\
\hline \multirow[t]{2}{*}{ Three-Factor CAR $(-2,+2)$} & -0.0022 & -0.0038 & -0.0002 & -0.0022 \\
\hline & $(-0.64)$ & $(-0.90)$ & $(-0.15)$ & $(-0.70)$ \\
\hline \# of Observations & 8,034 & 10,038 & 10,038 & 10,038 \\
\hline \multirow[t]{2}{*}{ Three-Factor BHAR $(-2,+2)$} & -0.0022 & -0.0037 & -0.0003 & -0.0024 \\
\hline & $(-0.65)$ & $(-0.90)$ & $(-0.18)$ & $(-0.77)$ \\
\hline \# of Observations & 8,034 & 10,038 & 10,038 & 10,038 \\
\hline \multirow[t]{2}{*}{ Four-Factor CAR $(-2,+2)$} & -0.0019 & -0.0039 & 0.0001 & -0.0018 \\
\hline & $(-0.55)$ & $(-0.88)$ & $(0.09)$ & $(-0.56)$ \\
\hline \# of Observations & 8,034 & 10,038 & 10,038 & 10,038 \\
\hline \multirow[t]{2}{*}{ Four-Factor BHAR $(-2,+2)$} & -0.0019 & -0.0038 & 0.0000 & -0.0020 \\
\hline & $(-0.55)$ & $(-0.89)$ & $(0.02)$ & $(-0.61)$ \\
\hline \# of Observations & 8,034 & 10,038 & 10,038 & 10,038 \\
\hline
\end{tabular}




\begin{tabular}{|c|c|c|c|c|}
\hline \multirow[t]{2}{*}{ Managerial Answer Certainty } & 0.0130 & -0.0127 & -0.0042 & 0.0124 \\
\hline & $(0.99)$ & $(-0.69)$ & $(-0.91)$ & $(1.29)$ \\
\hline \# of Observations & 51,449 & 60,861 & 60,861 & 60,861 \\
\hline \multicolumn{5}{|l|}{ Firm Performance: } \\
\hline \multirow[t]{2}{*}{$\mathrm{ROA}$} & 0.0115 & 0.0058 & $0.0067 * *$ & 0.0058 \\
\hline & $(1.14)$ & $(1.14)$ & $(2.11)$ & $(0.85)$ \\
\hline \# of Observations & 14,243 & 17,429 & 17,429 & 17,429 \\
\hline \multirow[t]{2}{*}{ Three-Factor CAR } & 0.0464 & -0.0084 & $0.0295 * * *$ & -0.0140 \\
\hline & $(1.30)$ & $(-0.30)$ & (3.11) & $(-1.23)$ \\
\hline \# of Observations & 14,810 & 18,075 & 18,075 & 18,075 \\
\hline \multirow[t]{2}{*}{ Three-Factor BHAR } & 0.0671 & 0.0210 & $0.0435 * * *$ & -0.0132 \\
\hline & $(1.10)$ & $(0.61)$ & $(2.70)$ & $(-0.42)$ \\
\hline \# of Observations & 14,810 & 18,075 & 18,075 & 18,075 \\
\hline \multirow[t]{2}{*}{ Four-Factor CAR } & 0.0516 & 0.0005 & $0.0220 * *$ & -0.0090 \\
\hline & $(1.42)$ & $(0.02)$ & $(2.07)$ & $(-0.99)$ \\
\hline \# of Observations & 14,810 & 18,075 & 18,075 & 18,075 \\
\hline \multirow[t]{2}{*}{ Four-Factor BHAR } & 0.0737 & 0.0368 & $0.0361 * *$ & -0.0099 \\
\hline & $(1.13)$ & $(1.04)$ & $(2.07)$ & $(-0.38)$ \\
\hline \# of Observations & 14,810 & 18,075 & 18,075 & 18,075 \\
\hline Control Variables & Yes & Yes & Yes & Yes \\
\hline Year Fixed Effect & Yes & Yes & Yes & Yes \\
\hline Industry Fixed Effect & Yes & Yes & Yes & Yes \\
\hline Clustered Std. Err. & Firm \& Year & Firm \& Year & Firm \& Year & Firm \& Year \\
\hline
\end{tabular}

